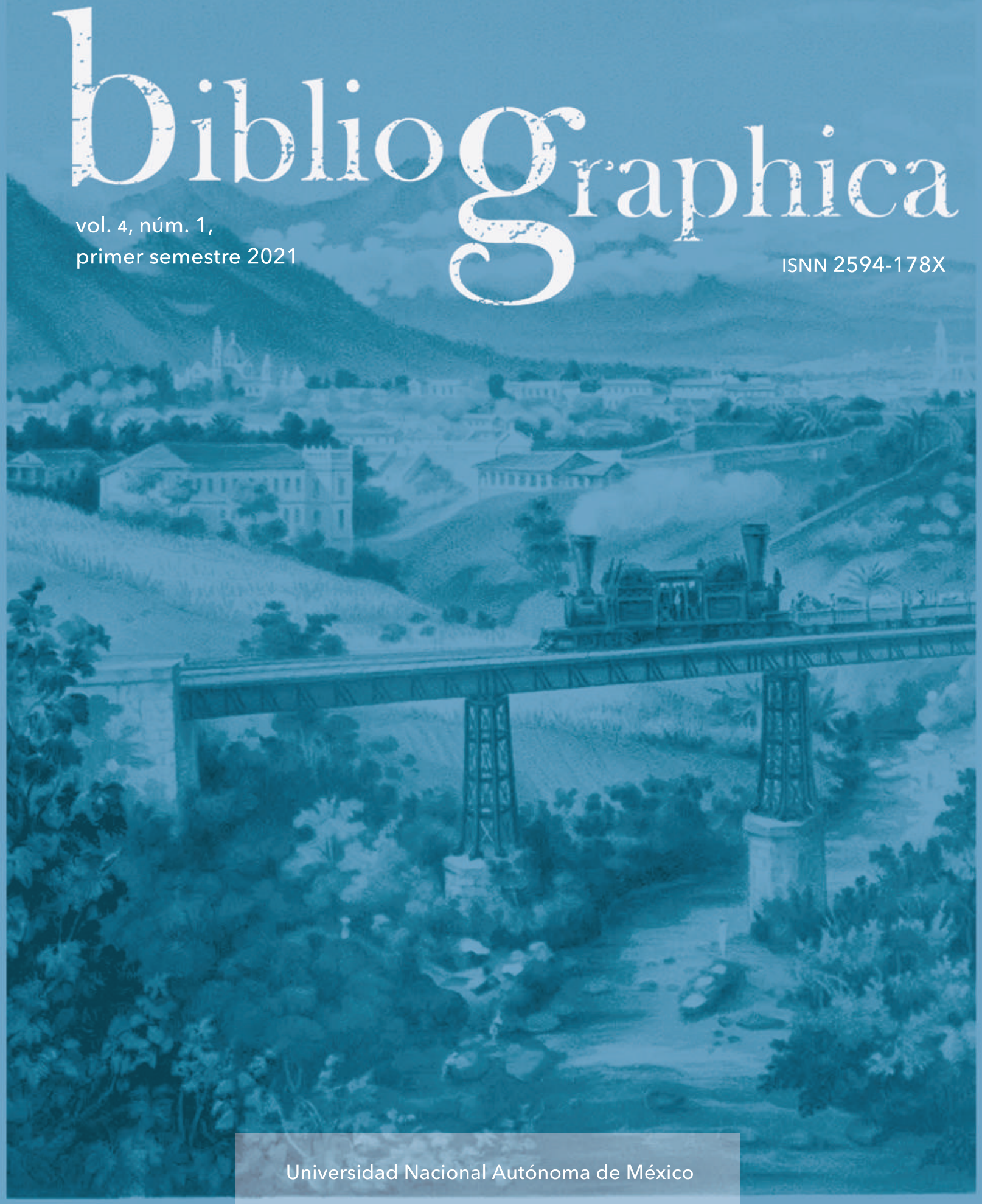




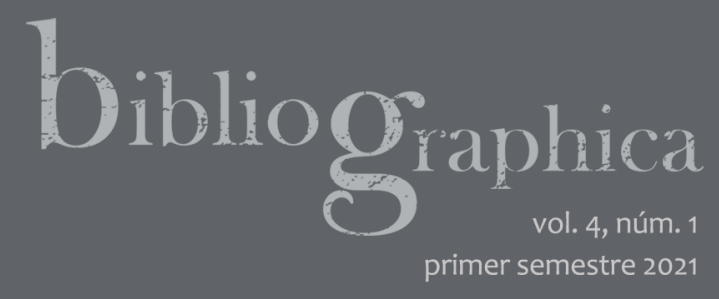

\section{Libros y objetos obscenos en Nueva España durante la segunda mitad del siglo XVIII}

Obscene Books and Objects in New Spain
during the Second Half of the $18^{\text {th }}$ Century

\section{Mariana López Hernández}

Universidad Nacional Autónoma de México,

Programa de Maestría en Historia,

Ciudad de México. México

samo.jmb10@hotmail.com

https://orcid.org/0000-0001-7905-4578

Recepción: 07.09.2020 / Aceptación: 26.10.2020

DOI: https://doi.org/10.22201/iib.2594178xe.2021.1.90 
Resumen Las pinturas y la literatura obscenas fueron prohibidas por el Santo Oficio español desde el siglo XVI hasta principios del XIX. Sin embargo, el análisis de varios expedientes inquisitoriales demuestra que tal censura no impidió su circulación en el virreinato de Nueva España. La riqueza de esas fuentes primarias permite ofrecer en estas páginas un panorama de la segunda mitad del siglo XVIII que abarca a los poseedores, los usos y las características de las obras consideradas obscenas por la autoridad inquisitorial.

Palabras clave

Abstract

Keywords
Inquisición; obscenidad; censura; Nueva España; literatura.

Obscene paintings and literature were forbidden by the Spanish Holy Office from the $16^{\text {th }}$ to the early $19^{\text {th }}$ centuries. Nevertheless, the analysis of various inquisitorial files proves that such censorship did not prevent their circulation in the viceroyalty of New Spain. The richness of those primary sources offers, in these pages, a panorama of the second half of the $18^{\text {th }}$ century that comprises the owners, the uses and the characteristics of the works that were considered obscene by the inquisitorial authority.

Inquisition; obscenity; censorship; New Spain; literature. 


\section{Introducción}

Tras la eclosión de la Reforma Protestante en Europa y su penetración en España hacia 1557, Felipe II destinó a la Inquisición la tarea de controlar y vigilar la circulación del libro impreso. ${ }^{1}$ Para hacer efectiva y práctica esta actividad, el Santo Oficio español elaboró índices de libros prohibidos, desde 1583 hasta 1790, es decir, "catálogos de libros vedados por la Iglesia por contener doctrinas heréticas, peligrosas o inmorales".2 Estas listas se sujetaron a las reglas que sintetizaron las características de los textos que no debían leerse, ${ }^{3}$ las cuales estuvieron vigentes hasta la extinción del Santo Oficio en 1820.

Entre las normas que regían la censura existieron dos que prohibieron las imágenes y los escritos "lascivos", también designados por la autoridad inquisitorial como obscenos, torpes, impúdicos, indecorosos, infames, vergonzosos, feos, indecentes, etc. ${ }^{4}$ Este amplio panorama de calificativos revela diversos problemas y, si escogemos uno de ellos, caben las preguntas ¿qué se entendía por obsceno?, ¿cómo concebir las imágenes o escritos así designados?, ¿qué características poseían esos objetos que los hacía merecedores de tales señalamientos?

El presente artículo tiene como objetivo contribuir a la resolución de estas preguntas, centrando su atención en el virreinato de Nueva España durante la

\footnotetext{
${ }^{1}$ Según Henry Kamen, en España "la amenaza luterana, tardó bastante en desarrollarse. En 1520 probablemente no habría todavía nadie en el territorio que hubiera oído hablar de Lutero". Los primeros focos protestantes fueron detectados en Castilla y Sevilla, donde en 1557 Juan Ponce de León fue detenido por introducir libros luteranos procedentes de Ginebra. Ante la amenaza, la regente Juana de Austria, en ausencia de Felipe II (que se había trasladado por un tiempo a los Países Bajos), dispuso que ningún comerciante debía introducir en Castilla libros en latín o romance impresos en otros reinos, obligó a los impresores a pedir licencias al Consejo y estableció un control muy estricto de actuación de censura. Sin embargo, estas medidas sólo afectaban a Castilla, por lo cual el gobierno no tuvo más remedio que ponerse en manos de la Inquisición, en su intento de supervisar la importación del libro en todo el territorio español. Henry Kamen, La inquisición española (Barcelona: Crítica, 2013), 135-161.

2 Juana Inés Fernández López et al., Vocabulario eclesiástico novohispano (México: INAH, 2015), 144-145.

3 José Abel Ramos Soriano, Los delincuentes de papel. Inquisición y libros en la Nueva España (1571-1820) (México: FCE, 2011), 46.

${ }^{4}$ María José Muñoz García, "Erotismo y celo inquisitorial. Expedientes de escritos obscenos censurados por la Inquisición en el siglo XVIII y principios del XIX", Cuadernos de Historia del Derecho, núm. 10 (2003): 176.
} 
segunda mitad del siglo XVIII. Para dicho propósito, se recurrirá a diversos expedientes inquisitoriales que ayudarán, primero, a establecer quiénes poseían este tipo de obras en el virreinato, después a indicar su uso y, al final, a señalar algunas características que tuvieron para ser consideradas "obscenas".

Antes de adentrarnos en el mundo novohispano dieciochesco, me parece necesario hacer tres acotaciones. En primer lugar, debe tomarse en cuenta que las normas establecidas en los índices de libros prohibidos tuvieron variaciones a lo largo del tiempo y la prohibición de libros e imágenes considerados "obscenos" fue paulatina. La regla XII del Índice de 1583 prohibía aquello que motivara la burla, el desacato e irreverencia hacia los santos o alguna de las dignidades de la Santa Sede como los papas, cardenales u obispos. La norma continuó los años siguientes hasta que en 1632 cambió su numeración al convertirse en la regla X. Una nueva variación apareció en el Índice de 1640, con la añadidura de un párrafo indicando "que ninguna persona sea osada a meter en estos Reinos imágenes de pintura, láminas, estatuas, o otras de escultura, lascivas, ni usar de ellas en lugares públicos de plazas, calles o aposentos comunes de las casas. Y assimismo se prohíbe a los pintores que no las pinten y a los artífices que no las tallen ni hagan, pena de excomunión mayor". ${ }^{5}$

Otra transformación puede observarse en la regla VII, que prohibía las "obras que tratan, cuentan y enseñan cosas de propósito lascivas, de amores y otras cualesquiera, como dañosas a las buenas costumbres de la lglesia cristiana, aunque no se mezclen en ellas herejías y errores: mandando que los que las tuvieren sean castigados por los inquisidores severamente". ${ }^{6}$ Esta norma había sido declarada por el papa Pío V en 1564 y, antes de incorporarla a sus índices, el Santo Oficio español consultó al jesuita Juan de Mariana y al inquisidor Jerónimo Zurita, para decidir si debía o no integrarse al primer catálogo español de $1583 .^{7}$

En España no se daba demasiada importancia a los escritos de la llamada "literatura recreativa" o de entretenimiento ni a la "literatura novelesca" de tema galante, puesto que eran considerados de poca utilidad y, por tanto, no se favorecía la impresión de libros que abarcaran esos tópicos. Debido a ello, los jueces tomaron en cuenta la opinión del inquisidor Zurita, quien consideró innecesaria

\footnotetext{
${ }^{5}$ Enrique Gacto, "El arte vigilado (sobre la censura estética de la Inquisición española en el siglo XVIII)", Revista de la Inquisición 200, núm. 9 (2000): 8-9.

${ }^{6}$ Muñoz García, "Erotismo y celo inquisitorial...", 176.

${ }^{7}$ Ramos Soriano, Los delincuentes de papel, 46.
} 
la inserción de la regla al catálogo español. Sin embargo, en 1612 se decidió integrarla y así permaneció en los subsecuentes índices. ${ }^{8}$

En segundo lugar, debemos recordar que el Tribunal del Santo Oficio fue establecido en Nueva España en 1571 y que uno de sus objetivos principales fue evitar la entrada y propagación de libros y folletos protestantes. ${ }^{9}$ Para conseguir ese propósito, el tribunal novohispano recurrió a la misma metodología y herramientas utilizadas en la península ibérica, y entre estas últimas se encontraban los índices mencionados. Por ello, la introducción de obras y representaciones obscenas al virreinato quedaba, desde finales del siglo XVI, estrictamente prohibida por la institución inquisitorial. Sin embargo, estas restricciones no desalentaron su ingreso a Nueva España, sino que proliferaron, en contra de lo esperado.

Por último, debo indicar que -respecto al siglo XVIII novohispano- algunas obras prohibidas han sido estudiadas desde el punto de vista de la censura, el uso y la producción. ${ }^{10}$ No obstante, es notable la ausencia de un desarrollo amplio del tema, ${ }^{11}$ si se le compara con el alcanzado en la península, abordado

8 Jesús Martínez Bujanda, "Literatura e Inquisición", en La Inquisición española: una nueva visión, nuevos horizontes, coord. de Joaquín Pérez Villanueva (México: Siglo XXI, 1980), 579-582. Muñoz García, "Erotismo y celo inquisitorial...", 172-176.

${ }^{9}$ Alicia Mayer, Lutero en el Paraíso. La Nueva España en el espejo del reformador alemán (México: FCE, 2008), 145-183. En cuanto al protestantismo, perseguido por el Tribunal del Santo Oficio como luteranismo, los aportes de esta obra son dignos de recalcar, pues la autora se ha interesado en estudiar la idea y la imagen que se creó en torno a Martín Lutero en Nueva España entre los siglos XVI y XVIII. En las páginas que cito, Mayer analiza la construcción de la imagen del reformador alemán y del luteranismo a través de documentos elaborados por la Inquisición, tales como la obra del calificador Dionisio Ribera Flores, procesos y denuncias.

${ }^{10}$ Désirée Moreno Silva, "Erotismo y censura en el siglo XVIII novohispano. Imágenes y objetos censurados por la Inquisición", en XXIII Coloquio Internacional de Historia del Arte. Amor y Desamor en las Artes, ed. de Arnulfo Herrera Curiel (México: UNAM, 2001), 353-373. Mariana Masera, "Bailes 'deshonestos' y sones perseguidos por la Inquisición novohispana", en Poéticas de la oralidad: las voces del imaginario (México: UNAM, 2014), 79-110.

${ }^{11}$ Sobre el siglo XVII, existen algunos análisis que abordan, desde la historia del arte, casos inquisitoriales sobre pinturas lascivas novohispanas. Uno de ellos trata acerca de la serie de lienzos que el marqués de Celada mandó hacer con pintores de la Ciudad de México. Las pinturas "deshonestas" representaban las "Fábulas" que Ovidio refiere en sus obras. Gustavo Curiel, "Ovidio censurado: los lienzos de pintura lasciva del marqués de Celada (historia de un proceso inquisitorial, 1692)", en La abolición del arte. XXI Coloquio Internacional de Historia del Arte, ed. de Alberto Dallal (México: UNAM, IIE, 1998), 273-315. 
principalmente desde la literatura, ${ }^{12}$ enfoque que ha permitido conocer el perfil del lector de escritos obscenos: hombres entre los 20 y 30 años, "universitarios (más legos que clérigos), militares (soldados o marineros) extranjeros (sobre todo franceses), funcionarios, de profesiones liberales, y heterodoxos intelectuales y cultos los más (ya que se trataba de leer libros)". ${ }^{13}$

\section{Variedad de objetos entre una infinidad de personas}

En México, en el ramo Inquisición del Archivo General de la Nación, pueden consultarse expedientes que refieren el delito de obscenidad y dan cuenta de la existencia de diversos objetos que circularon a lo largo de la segunda mitad del siglo XVIII en Nueva España. ${ }^{14}$ Se trata de un universo integrado por lienzos, mancuernillas, medallas, láminas, dijes, relojes y sus cadenas, estampas, libros, abanicos, cajas y espejos. Muchas veces, por la naturaleza del expediente, no es posible identificar la técnica y el material con el que fueron hechos estos objetos, pero se pueden conocer otras características relevantes, como el sexo

y la edad de los poseedores, ya que en nuestra pequeña muestra encontramos a hombres -salvo un caso relacionado con mujeres- entre 20 y 52 años.

Cuatro de ellos fueron empleados reales que prestaron y exhibieron estos objetos a terceros que, asombrados por la naturaleza de la imagen, denunciaron al poseedor ante el Tribunal del Santo Oficio. Fue el caso, por ejemplo, de una "cajuela" (caja pequeña) de plata cuyo original, según el denunciante, pertenecía a "un hombre de renombre" que la prestó a Antonio Leonel de Cervantes, oficial segundo de la Casa de Moneda, quien la enseñó a Ignacio Pérez Gallardo, abogado de la Real Audiencia. ${ }^{15}$ Lo mismo pasó con dos estampas que

\footnotetext{
12 Véanse los trabajos de Victoria Galván González, "La literatura erótica de la Ilustración española", en La palabra y el deseo. Estudio de literatura erótica, coord. de Germán Santana Henríquez (Gran Canaria: Universidad de Las Palmas de Gran Canaria, 2002), 117-134; David T. Gies, "Sobre el erotismo rococó en la poesía del siglo XVIII español", en Luz Vital: estudios de cultura hispánica en memoria de Victor Ouimette, ed. de Ramón F. Llorens y Jesús Pérez Magallón (Alicante: Caja de Ahorros del Mediterráneo, 1999), 85-95; e Iris Zavala, "Inquisición, erotismo, pornografía y normas literarias en el siglo XVIII", Anales de Literatura Española, núm. 2 (1983): 509-528.

${ }^{13}$ María José Muñoz García, "La censura inquisitorial de publicaciones obscenas", en Inquisición y censura: el acoso a la inteligencia en España, coord. de Enrique Gacto Fernández (Madrid: Dykinson, 2006), 515.

${ }^{14}$ Moreno Silva, "Erotismo y censura...", 353.

${ }^{15}$ Archivo General de la Nación (AGN), Inquisición, vol. 1098, exp. 8, f. 400.
} 
fueron prestadas por Joseph Casimiro Espinoza, abogado de la Real Audiencia de Chile y Perú, a Diego Manzanillas, el cual las mostró al comisario de la Inquisición. ${ }^{16}$ Estas estampas, junto con otras, fueron enviadas a Domingo Enriquena, administrador de Alcabalas, quien las reveló a Mariana de Torres, hija de Joseph Mariano de Torres, abogado y relator de la Real Aduana. ${ }^{17}$

Otros poseedores fueron comerciantes, como Francisco Barroso Yturbia, a quien le remitieron un reloj desde el extranjero por medio de Juan Antonio Camaño, ${ }^{18}$ y se puede suponer que sería vendido. Francisco Garfias ofrecía en su tienda una gran variedad de estampas calificadas como obscenas, por lo que el comisario de la Inquisición hizo una revisión exhaustiva de la oferta y le confiscó 465 estampas, cuyo precio total aproximado habría sido de 180 pesos y 5 reales. ${ }^{19}$ Estos objetos pasaban a manos de los clientes, a quienes eran vendidos o incluso obsequiados como "pilón", ${ }^{20}$ según lo hacía el francés Joaquín el Chino, quien vendió un espejo miniatura con una pintura obscena, mientras que a otro cliente regaló un abanico con una imagen oculta. ${ }^{21}$

Otro grupo de poseedores fueron algunos militares pertenecientes a distintos cuerpos del Ejército, como José Galván, integrante del Regimiento de la Corona, denunciado por tener una cadena de reloj con varios dijes, entre los cuales había una lámina pequeña de marfil "impura y obscena". 22 El cadete Juan Bautista Maestre, del Regimiento de Nueva España, fue delatado por tener libros como Histoire de Gouberdon, ${ }^{23}$ en tanto que a Miguel Avilés, teniente del Regimiento de Dragones de España, lo delataron por tener L'Academie des

${ }_{16}$ Ibid., vol. 1167, exp. 24, ff. 379-382.

17 Ibid., vol. 1307, exp. 13, ff. 93-94.

18 Ibid., vol. 1126, exp. 37, ff. 260-265.

$19 \mathrm{lbid} .$, vol. 1167, exp. 20. El precio total se ha calculado a partir de los datos que el comisario proporciona sobre las estampas. Menciona que recogió 465: 105 grandes que valían entre 5 y 6 reales, 200 medianas con un precio entre 3 y $31 / 2$ reales y 160 chicas con precio de 2 reales.

${ }^{20}$ La expresión hace referencia a "lo que el vendedor da de gratis sobre el precio de lo que se compra". Guido Gómez de Silva, Diccionario breve de mexicanismos (México: FCE, 2004), 176.

${ }^{21}$ AGN, Inquisición, vol. 1355, exp. 7, f. 20.

22 Ibid., vol. 1230, exp. 8, ff. 162-165.

${ }^{23}$ El expediente indica el título como "Histoire de Gouberdon", lo cual sugiere que probablemente se trata de la traducción inglesa The Life and Saturnin de Gouberdon, de la obra Histoire de dom B. AGN, Inquisición, vol. 1373, exp. 11, ff. 104-132. Julie Peakman, Amatory Pleasures: Explorations in Eighteen-Century Sexual Culture (Londres; Nueva York: Bloomsbury Publishing, 2016), 207. 
Dames, títulos de los que hablaremos más adelante. A estos casos debe agregarse el del coronel de dragones Agustín Beven, denunciado por utilizar "unas cajitas", probablemente relacionadas con el uso del tabaco. ${ }^{24}$

De tal manera, empleados reales, comerciantes y militares encabezan la lista de poseedores, a los que se suman individuos provenientes de otros oficios y profesiones, como el cirujano Antonio Velázquez, de quien al morir se hallaron en su propiedad "unas pinturas muy obscenas", las cuales fueron recogidas por el comisario Bolea después de que el defensor de los bienes del difunto, Manuel Joachin Hidalgo, diera cuenta al Tribunal. ${ }^{25}$ Otro caso fue el del platero José Luis Rodríguez, que tenía en su local unas "estampas obscenas", algunas sueltas y otras enmarcadas. ${ }^{26}$ El relojero Juan Sabey fue denunciado por mandar hacer con el pintor Alfaro una imagen que representaba una pulquería donde se apreciaba a "una mujer en aptitud de hacer aguas menores", es decir, en actitud de orinar, escena que nos remite al grabado A Woman Making Water, elaborado por Rembrandt en 1631. No sólo dicha estampa fue recogida, sino que junto con ella se retiró otra "formada por cuerpos desnudos, de hombres y mujeres, envueltos en placeres sexuales", que el titiritero o "jugador de manos" mister Falconi había regalado al mismo pintor. ${ }^{27}$

Por último, llama la atención el expediente en contra de Luis Martín, maestro arquitecto pensionado de la Real Academia de San Carlos, denunciado en 1794 por el maestro de sastrería Joaquín Botella. Además de exponer las proposiciones que le había escuchado al académico, señaló que un día Martín le había dicho que tenía libros prohibidos. Supo también que los "tenía escondidos tras de los otros y que unas estampas obscenas que tenía las iba a vender a peso a un majadero que las quería". Inmediatamente los inquisidores ordenaron al calificador marqués de Castañiza que acudiera a casa del maestro para reconocer sus libros, papeles y estampas, además de recoger "cuantas les parezcan deshonestas y de los libros cuantos halle prohibidos y sospechosos, lo mismo de papeles". ${ }^{28}$

\footnotetext{
${ }^{24}$ AGN, Inquisición, vol. 1167, exp. 23.

${ }^{25}$ Ibid., vol. 1355, exp. 6, f. 45.

26 Ibid., vol. 1398, exp. 6, f. s. n.

${ }^{27}$ Moreno Silva, "Erotismo y censura...", 362, 363.

${ }^{28}$ AGN, Inquisición, vol. 1340, exp. 5, ff. 8, 9.
} 


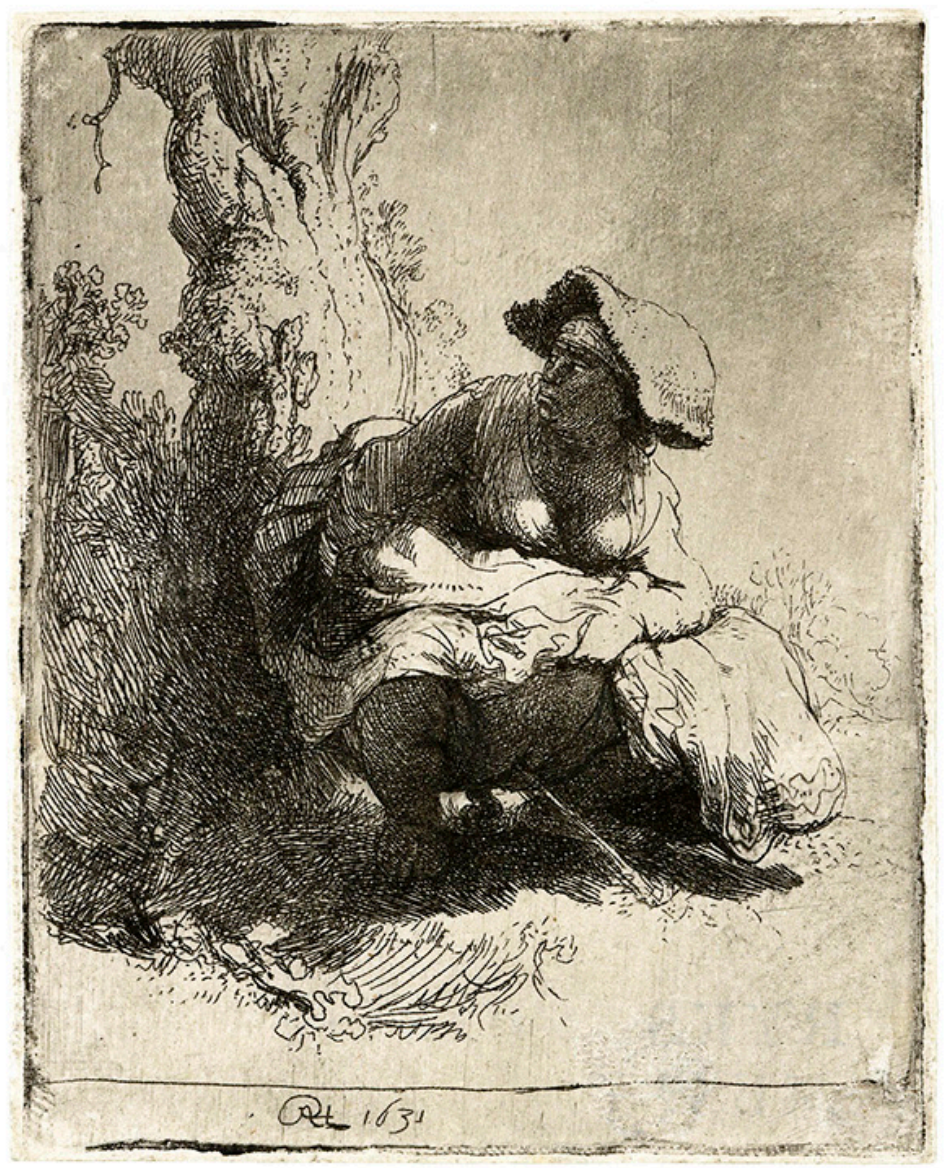

Imagen 1. Juan Sabey fue denunciado por mandar pintar la imagen de una mujer en actitud de orinar, similar a la de Rembrandt, $A$ Woman Making Water, RHL (monograma) 1631, aguafuerte, 81 x 64 mm. Colección de Rijksmuseum.

El comisario llevó a cabo la labor asignada y dio aviso a los inquisidores de no haber encontrado libros prohibidos, pero sí muchas estampas "indecentes", las cuales se encontraban "en un cajón sobre una tabla debajo de la mesa, entre otra porción de dibujo y planes [sic] propios de su ejercicio y otras que son de las menos malas y alusivas a la fábula, elevadas en la pared". ${ }^{29}$ Su ubicación in-

${ }^{29}$ Ibid., f. 10. 
dica que el arquitecto las utilizaba como adorno de la habitación y para su desempeño profesional, algo usual en su ámbito, baste recordar que en el edificio de la Academia, las estampas constituían las primeras herramientas de los discípulos, pues su formación iniciaba en la sala de principios, donde ejercitaban la copia de estampas y dibujos clásicos. Tras años de práctica, se acercaban a los libros teóricos de anatomía, geometría y perspectiva, ubicados en estantes de las salas de enseñanza, en los talleres y galerías, además de la sala de lectura. ${ }^{30}$

Después de que la biblioteca y lo papeles de Luis Martín fueron inspeccionados, el marqués de Castañiza tomó la declaración del denunciado, para conocer el modo en que había conseguido esas estampas. El maestro arquitecto indicó que había adquirido las imágenes "indecentes por el fin de dibujo" en la calle de Santo Domingo, en una tienda de mercería, mientras que la que tenía escrito en el reverso "La Academia", se la había dado Bernardo Gil cuando le manifestó no tener alguna "para el dibujo de mujer desnuda". El denunciado añadió que no creía que sus estampas deberían ser recogidas, debido al uso que les daba y por "haber visto otras por el mismo estilo en la Academia públicamente". ${ }^{31}$

En efecto, la biblioteca de esa institución resguardaba estampas, dibujos y tratados que, a pesar de circular prestados en las diferentes salas del edificio, eran resguardados por un conserje y no salían del recinto. Por tanto, probablemente su circulación se consideraba privada, de tal forma que el uso de estos impresos bajo esas condiciones podía no contravenir la regla XI de los índices de libros. Sin embargo, al tener estas imágenes en su domicilio, el arquitecto Martín infringía la regla mencionada.

Por otra parte, cabe preguntarse: ¿cómo llegaron estos objetos al virreinato novohispano? Gracias a algunos expedientes se conoce que ingresaron en los navíos cargados de mercancías provenientes de Europa y China que arribaban a los puertos de Veracruz y Acapulco. También muestran su distribución tierra adentro, hacia Puebla de los Ángeles y la Ciudad de México, como fue el caso de un reloj denunciado y recogido, en el navío de Filipinas La Concepción, a Juan Antonio Camaño, quien en su declaración ante el comisario de la Inquisi-

\footnotetext{
${ }^{30}$ Kenya Bello, "Una biblioteca para artistas. La Academia de San Carlos y la lectura pública (1785-1843)", en Estantes para los impresos. Espacios para los lectores. Siglos XVII-XIX, coord. de Laura Suárez de la Torre (México: Instituto de Investigaciones Dr. José María Luis Mora / Conacyt, 2017), 230-231.

${ }^{31}$ AGN, Inquisición, vol. 1340, exp. 5, f. 10.
} 
ción dijo haberlo remitido por correo a la Ciudad de México, a su dueño original Francisco Barroso. ${ }^{32}$

Si bien muchos de los objetos denunciados al Tribunal provenían de Europa y Asia, cabe decir que también fueron elaborados dentro del virreinato, por ejemplo tenemos el caso del mencionado José Alfaro o el de José Salazar que, al arribar a Veracruz, se dio a conocer como pintor de sobresaliente habilidad. Al ver el talento de Salazar, el oficial de la Contaduría de la Real Hacienda José María Guido decidió hospedarlo en su casa de aquel puerto. Según informó el casero, después de un tiempo Salazar desapareció sin motivo ni razón, tras lo cual Guido reparó en que su huésped pasaba mucho tiempo en "formar pinturas deshonestas", y así recordó una ocasión cuando lo vio escribir en un abanico unos versos impuros en francés, acto que comunicó a la Inquisición. ${ }^{33}$

Otra producción novohispana fue el cuadernillo intitulado "Amor del Tiempo", cuya censura/prohibición constituye el único caso hasta ahora localizado donde las mujeres aparecen relacionadas con la creación y posesión de obras obscenas. Se dijo que los seis sonetos que conformaban el manuscrito fueron compuestos por alguna monja dentro del Convento de las Capuchinas de Guadalajara. Ante los ojos del calificador fray Domingo de Gandarias, el texto era "un compendio, aunque en términos disimulados, de los pasajes que ocasiona un amor lascivo desde sus primeros pasos hasta sus lamentables fines, individualizando los más vergonzosos deslices sin rubor alguno". ${ }^{34} \mathrm{Nada}$ se supo sobre la autoría y circulación del manuscrito, pues si bien los inquisidores mandaron interrogar a Salvador Antonio Verdín, quien había recogido la obra del convento referido y la había mandado al Tribunal, no pudo decir nada al respecto porque le había sido entregada al capellán durante la confesión, lo que obligaba confidencialidad. ${ }^{35}$

Como mencioné, estos expedientes revelan la existencia de una variedad de objetos que en su mayoría cumplieron con la función de ser lucidos, como alhajas o imágenes, y al tiempo que ornamentaban el atuendo personal, llamaban la atención por la imagen agregada. Es decir, se trataba de un adorno o accesorio que contribuía a embellecer la apariencia de las personas y del

\footnotetext{
32 Ibid., vol. 1126, exp. 37, ff. 260-267.

${ }_{33}$ Ibid., vol. 1368, f. 113.

${ }^{34}$ Ibid., vol. 1300, f. 132.

${ }^{35}$ El cuadernillo fue transcrito y se encuentra en José Miranda y Pablo González Casanova, Sátira anónima del siglo XVIII (México: FCE, 1953), 131-135.
} 
objeto mismo. En cuanto al manuscrito referido y los libros acompañados de imágenes que expondremos a continuación, puede pensarse que su uso era recreativo y de entretenimiento, pero ¿qué los convertía en obscenos?

\section{El artificio y la obscenidad}

Algunos expedientes describen de manera general el objeto considerado obsceno y anuncian que la imagen sobresaliente es la de una mujer. Existe, por ejemplo, la noticia de que en 1752 circulaban en Puebla unas mancuernillas o botones con la imagen estampada "de medio cuerpo abajo de una mujer con la mayor indecencia que pueda imaginarse". ${ }^{36}$ Décadas más tarde, se denunció un reloj que contenía la miniatura de "una mujer a medio cubrirse con una sábana y casi todo el cuerpo desnudo". ${ }^{37}$ En 1777, el dominico fray Vicente del Rosario dio aviso de que en una tienda de Oaxaca se vendían estampas que "tienen algunas madamas algo indecentes, por tener descubierto el pecho". ${ }^{38}$

A simple vista, las someras descripciones de estos artificios pueden parecer "pornográficas", sin embargo, hay que tener en cuenta que en el siglo XVIII no existía tal noción. ${ }^{39}$ Por fortuna existen otros expedientes que proporcionan elementos para comprender qué se consideraba "obsceno" en la segunda mitad de esa centuria en Nueva España. Es el caso del legajo formado con motivo de dos estampas que fueron mostradas a Agustín de Burgos, comisario del Santo Oficio en Veracruz, por Diego de Manzanillas, quien las pidió prestadas a Joseph Casimiro Espinoza. En una estampa se consideró "deshonesta" la "figura de una mujer con la ropa hasta la rodilla, traje acostumbrado por las señoras del reino de Lima", es decir, las mujeres que pertenecían a las esferas más altas de la sociedad limeña. La otra estampa presentaba una "campaña de las amazonas", ${ }^{40}$ lo cual puede entenderse como un combate de las mujeres guerreras míticas del mundo antiguo y que remite, por ejemplo, a los grabados de la obra de André Thevet donde aparecen desnudas.

\footnotetext{
${ }^{36}$ AGN, Inquisición, vol. 976, ff. 54-55.

${ }^{37}$ Ibid., vol. 1126, ff. 260-265.

38 Ibid., vol. 1167, f. 361.

${ }^{39}$ La noción de pornografía se desarrolló hasta el siglo XIX, "cuando los bibliotecarios almacenaron los libros que consideraban sucios y los pusieron bajo llave en secciones tabú". Robert Darnton, Los best sellers prohibidos en Francia antes de la Revolución (México: FCE, 2014), 143.

${ }^{40}$ AGN, Inquisición, vol. 1167, ff. 379-382.
} 


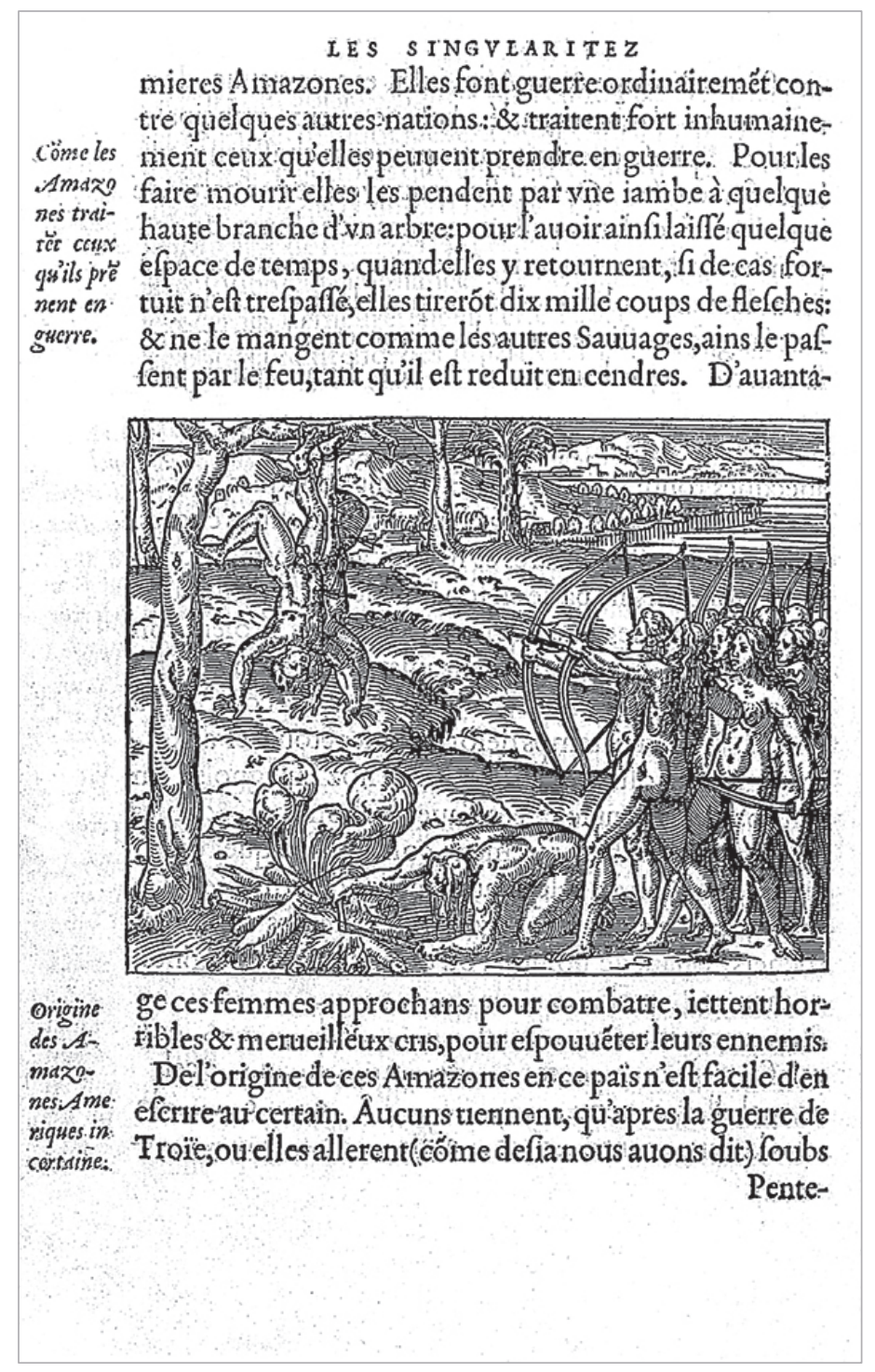

Imagen 2. En Nueva España circuló una estampa sobre "una campaña de las amazonas". Jean Cousin, "Amazones exécutant leurs ennemis, pendus par les pieds", grabado en Illustrations de Les singularités de la France antarctique, de André Thevet (1558), 127. Biblioteca Nacional de Francia (BNF). 
La primera estampa nos remite a los cambios en la manera de vestir, la apariencia, a inicios del siglo XVIII con el advenimiento de la casa Borbón en España. Se ha afirmado que la moda francesa fue adoptada tanto en la península como en los territorios americanos:

el propio Felipe V, en su afán por introducir la moda francesa, hizo circular anónimamente un escrito que cuestionaba el cuello de golilla y proponía el uso de la corbata de lazo implantada en Francia. Ya para 1707 su corte en pleno había adoptado el vestido francés y durante todo el siglo XVIII los trajes de la corte española y de sus representantes en las colonias americanas, fueron consistentemente copia de la moda francesa, imitados a su vez por los criollos prominentes de los virreinatos de las Indias. ${ }^{41}$

En Nueva España este cambio en la moda fue visible durante esa época, por ejemplo, en el uniforme de los soldados del palacio, "vestidos de paño azul y mangas encarnadas y medias del mismo color y sombrero de tres picos al uso de Francia". ${ }^{22}$ Así, la moda francesa introdujo en la monarquía hispánica, especialmente en Lima, los "trajes de corte", que en el caso femenino estaban conformados por:

la saya del siglo anterior -falda con pliegues acolchonados que ahora podía llevarse hasta media pierna o prolongarse hasta los tobillos- a lo que se agrega la camisa o jubón, pero modificándose algunas de sus características: las mangas se llevan a medio brazo (aunque se les aplican encajes y blondas en un afán por cubrir la piel), el escote se vuelve redondeado dejando al descubierto el cuello y el pecho, favoreciendo estos diseños el uso de gargantillas, collares y broches, por un lado, y de cintos, brazaletes y pulseras, de otro. ${ }^{43}$

Las transformaciones en el vestuario femenino, por ejemplo el uso del miriñaque ${ }^{44}$ provocaron severas críticas, particularmente el uso de esta pieza y la señalaban como "nada más opuesta al pudor, la modestia y a las buenas

${ }^{41}$ Scarlett O'Phelan Godoy, "La moda francesa y el terremoto de Lima", Bulletin de I'Institut Français d'Études Andines 36, núm. 1 (2007): 23.

${ }^{42}$ Miranda y González Casanova, Sátira anónima, 13.

${ }^{43}$ O'Phelan Godoy, "La moda francesa...", 23.

${ }^{44}$ Poderoso armatoste de rígida armadura entrelazada, a base de maderas, mimbres y ballenas, que se utilizaba para sostener y ampliar el vuelo de las ropas exteriores. Lola Gavarrón, Piel de ángel. Historias de la ropa interior femenina (Barcelona: Tusquets, 1988), 103. 


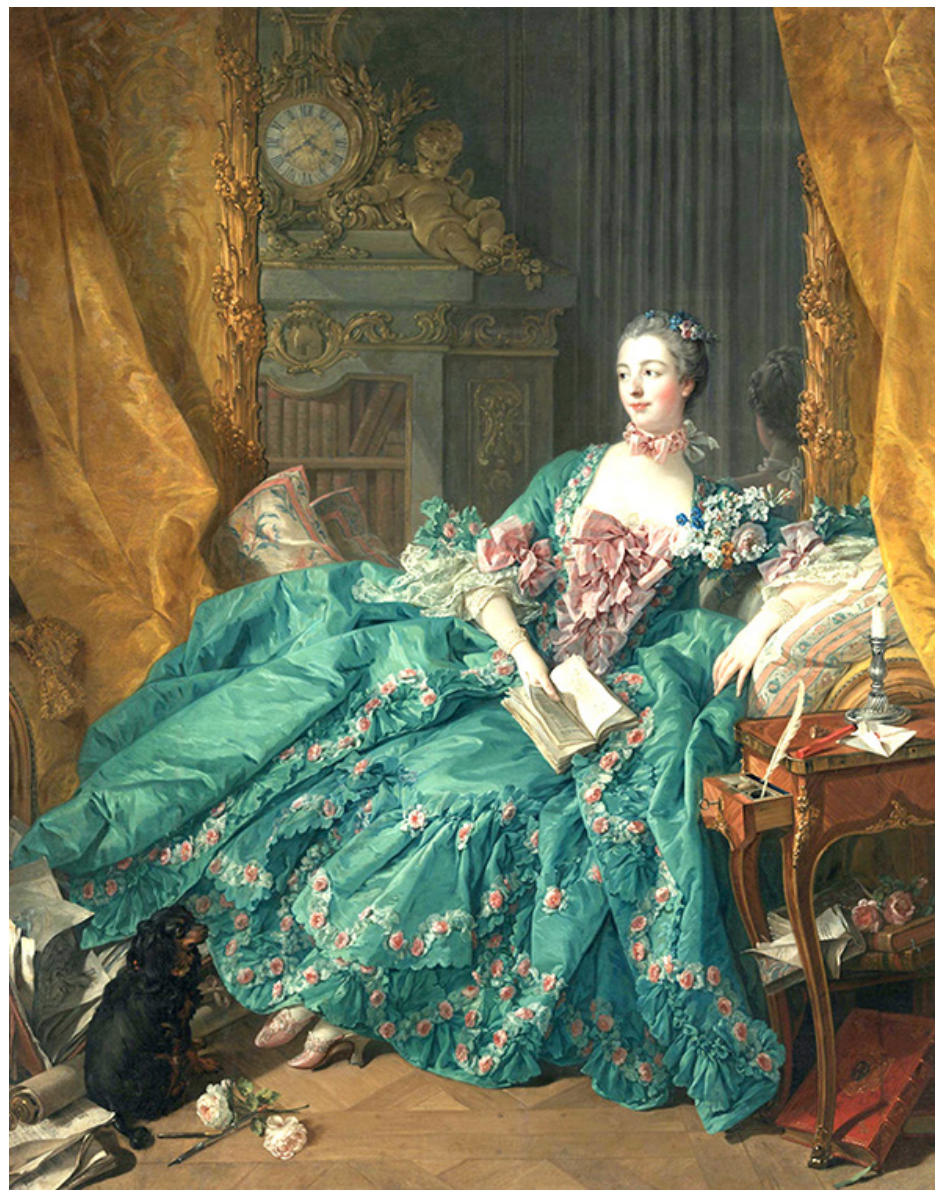

Imagen 3. La moda francesa del siglo XVIII incitaba al pecado, por dejar al descubierto el pecho, los brazos y los pies. François Boucher, La marquise de Pompadour, 1756, óleo, 202 × 157 cm. Colección Alte Pinakothek de Múnich.

costumbres", porque al aumentar el contorno del vestido "traía consigo la desnudez, la atención que provoca origina malos pensamientos y reflexiones obscenas". ${ }^{45}$ Para entender por qué se desaprobaba esta manera de vestir y su representación en estampas, hay que tener en cuenta que debajo del miriñaque

$\overline{45}$ O'Phelan Godoy, "La moda francesa...", 23. 
las damas no portaban ninguna otra prenda y, por tanto, se creía que incitaban "al pecado a los desdichados hombres". Más provocador se volvía el atuendo cuando las damas se caían "del caballo, de las diligencias o de sí mismas, mostrando al aire sus fesses vagabondes, ${ }^{46}$ lo que se traduce como "nalgas vagabundas". A pesar de estos estrictos juicios, las limeñas fueron proclives a seguir la moda francesa, que disminuía gradualmente el largo de la falda, sobre todo porque la pequeñez de sus pies era, para la época, uno de sus atributos de belleza más apreciados. ${ }^{47}$

El modo de vestir dieciochesco francés puede apreciarse en el retrato de madame Pompadour, pintado por François Boucher, así como en el de María Antonieta, por Vigée Lebrun. Lo mismo ocurre en el ámbito americano con el cuadro limeño denominado Retrato de una señora principal con su negra esclava, de Vicente Albán, y en el de la novohispana Mariana de Berrio.

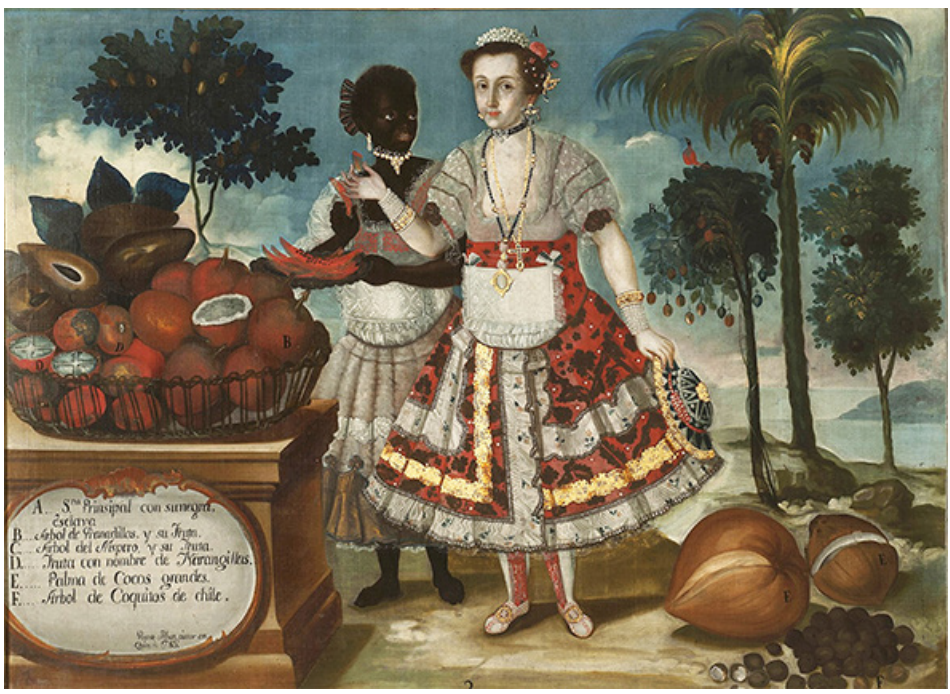

Imagen 4. El atuendo limeño siguió la moda francesa del siglo XVIII, al dejar ver el pecho, los antebrazos y tobillos. Vicente Albán, Retrato de una señora principal con su negra esclava, 1783, óleo sobre tela, 80 × 109 cm. Colección Museo de América de Madrid.

${ }^{46}$ Gavarrón, Piel de ángel, 103-104.

${ }^{47}$ Hay noticia de que la gente se burlaba continuamente de las españolas y algunas criollas por tener los pies demasiado grandes, mientras que admiraban los pies de las mujeres de la élite limeña, que portaban zapatos menudos y cerrados con hebillas de diamantes. O’Phelan Godoy, "La moda francesa....", 24. 
Estas fuentes pictóricas remiten al espectador no sólo a la moda del siglo XVIII, sino también a lo que en ocasiones fue interpretado por el Tribunal del Santo Oficio como obsceno o lascivo. En otras palabras, si no es posible recuperar la estampa que poseía Joseph Casimiro Espinoza denunciada ante la Inquisición, artificios como los retratos iconográficos nos acercan a las representaciones que "incitaban al pecado a los desdichados hombres". Sin embargo, como veremos enseguida, no son las únicas herramientas que un investigador puede utilizar para entender lo que en el siglo XVIII se calificaba de "obsceno".

\section{"El acto más impuro" en estampas y libros}

Tan diversos fueron los objetos obscenos como común el motivo por el que así fueron calificados, según los casos que hemos expuesto, ocurridos en el transcurso de dos décadas. En 1772 fue denunciado José Galván, sargento del Regimiento de la Corona, por tratar de vender a un relojero una cadena de oro para reloj de bolsillo con varios dijes, entre los cuales había uno de marfil o hueso que representaba "el acto más impuro". ${ }^{48}$ Esta descripción se asemeja a la hecha en 1783 sobre una pintura escondida en un reloj, que representaba a "un hombre y una mujer en acción sumamente deshonesta y provocativa", ${ }^{49}$ y a la de 1786 sobre una estampa que descubre "en sus lineamientos hombres y mujeres en acto torpe y deshonestísimo", ${ }^{50}$ una más que indicaba la existencia en 1791 de una estampa que ilustraba a un hombre y una mujer en una cama, donde ella estaba "desabrochada" y con los pechos "desabiertos en ademán bastante provocativo". ${ }^{51}$ Algunos expedientes formados en contra de militares nos permiten conocer a qué se refieren estos señalamientos, y apreciar las imágenes en su versión original.

El primero de ellos data de 1797, cuando el bachiller Joaquín López de Paliza denunció ante el tribunal inquisitorial que un cadete del Regimiento de Infantería de Nueva España, apellidado Maestry, tenía un libro con estampas "bastante indecentes". ${ }^{52}$ De inmediato, el brigadier Garibay, junto con el padre Bolea, recogieron la obra y la entregaron al Tribunal. El título en cuestión

\footnotetext{
${ }^{48}$ AGN, Inquisición, vol. 1320, exp. 8, ff. 162-165.

49 Ibid., vol. 1255, exp. 4, ff. 25-32.

50 lbid., vol. 1216, exp. 5, ff. 141-224.

${ }^{51}$ Ibid., vol. 1307, exp. 13, ff. 93-118.

52 Ibid., vol. 1373, exp. 11, f. 104.
} 
era Félicia ou mes fredaines, novela del militar André-Robert de Nerciat (17391800), ${ }^{53}$ donde la protagonista platica sobre su vida amorosa -entiéndase sexual-, con el fin de convencer al lector de seguir su modus vivendi. La primera edición de esta novela apareció en Londres en 1775 y al parecer tuvo gran éxito, puesto que hoy podemos contar 21 ediciones producidas en lo que resta de esa centuria. ${ }^{54}$

Como era de esperar, la autoridad inquisitorial no la acogió con el mismo ánimo, ya que su censura fue bastante enérgica. Según refiere María José Muñoz García, fue considerada una "novela detestable, infectada de proposiciones para pervertir, desde principio al fin las locuras son una purísima impureza, un arte para formar prostitutas y jóvenes disolutas, en ellas se refieren los actos torpes que ofenden el pudor, está comprendida en la regla $7^{a}$, es obscena en sumo grado y sumamente perjudicial a las buenas costumbres". ${ }^{55}$ Debido a que la única referencia registrada en el expediente es el formato "in-8", hasta ahora ha sido imposible encontrar la edición que ingresó al virreinato de Nueva España, sin embargo, es posible comprender la connotación del término "obsceno" al observar los 24 grabados hechos por Borel para la edición impresa en Londres (1782), donde queda clara su equiparación con lo sexual. ${ }^{56}$

Casi un año después de la denuncia del bachiller López de Paliza, llegó al Tribunal de la Inquisición la noticia de que Francisco González de Santiañés, alférez del mismo regimiento de infantería, tenía la primera parte de "un libro que parecía ser obsceno y escandaloso". ${ }^{57}$ Se trataba de Histoire de dom B, atribuido a Jean-Charles Gervaise de Latouche y, en efecto, como lo muestra la edición de 1748 , el texto de su primera parte podía contener 12 grabados que ilustran

\footnotetext{
${ }^{53}$ Formó parte del batallón de infantería de las milicias provinciales de Borgoña y del regimiento de Oldenburg, en Dinamarca. Raymond Trousson, "Andréa de Nerciat, Félicia ou mes fredaines, 1775", en Romans libertins du XVIIle siècle, coord. de Raymond Trousson (París: Robert Laffont, 1993), 1051.

${ }_{54}$ Guillaume Apollinaire, Introducción y ensayo bibliográfico a L'Oeuvre du chevalier Andréa de Nerciat (París: Bibliothèque des Curieux, 1921), 1-55.

${ }_{55}$ Muñoz García, "La censura inquisitorial...", 520.

${ }^{56}$ André-Robert de Nerciat, Félicia ou mes fredaines, orné de figures en taille-douce. Tome 1, Partie 1 (Londres, 1782), acceso el 14 de septiembre de 2020, https://gallica.bnf. fr/ark:/12148/bpt6k1073304q/f13.planchecontact.r=F\%C3\%A9licia\%20ou\%20Mes\%20 fredaines.

${ }^{57}$ AGN, Inquisición, vol. 1373, exp. 11, f. 105.
} 


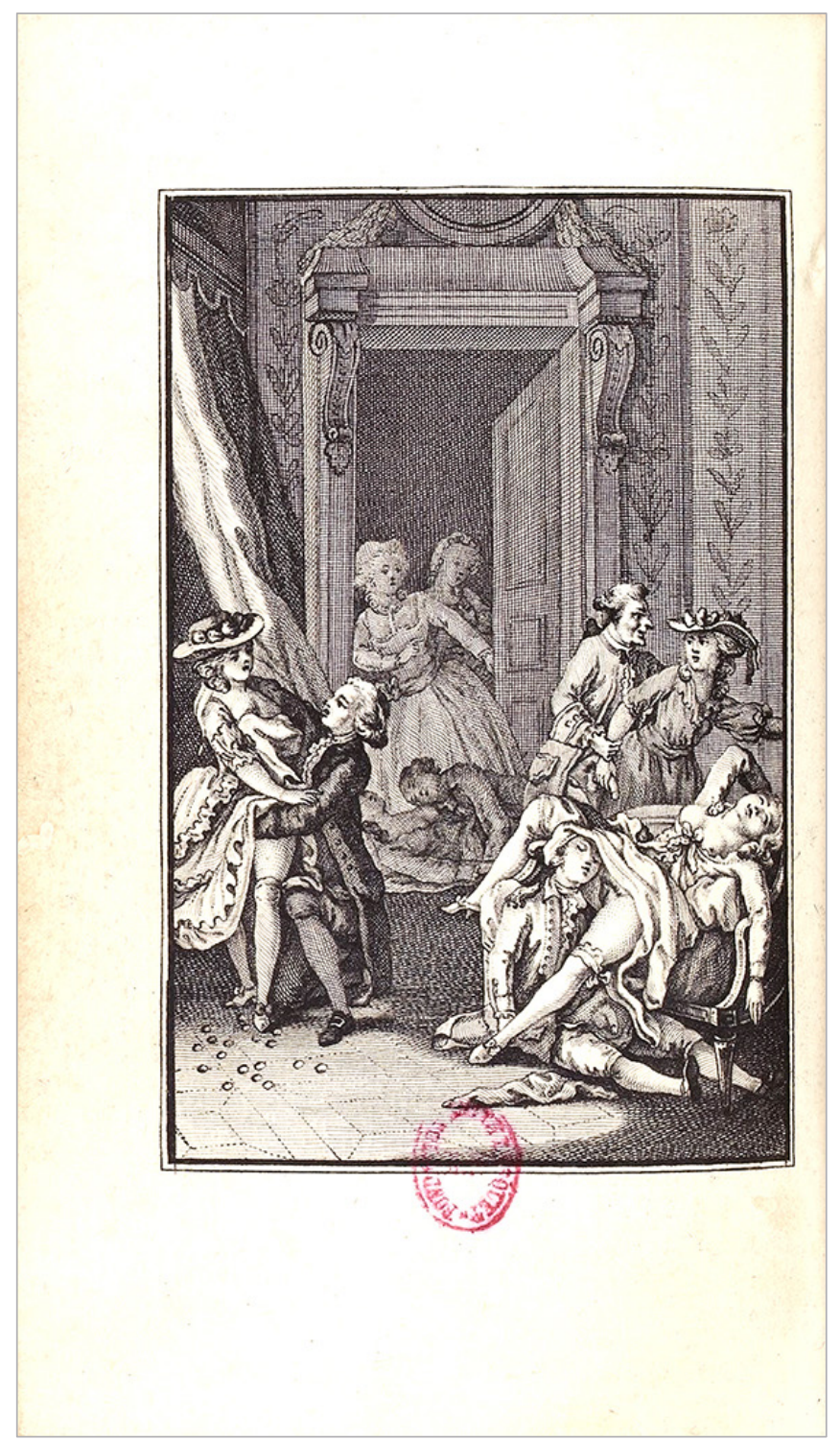

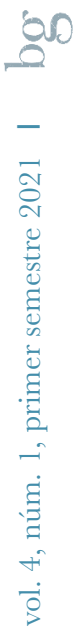

Imagen 5. Libros de tradición erótica francesa circularon entre los militares novohispanos. André-Robert de Nerciat, Félicia ou mes fredaines, orné de figures, t. II, parte 2 (Londres, 1782). BNF. 
y resumen el relato. ${ }^{58}$ Algunos investigadores han señalado que este título fue considerado durante mucho tiempo un "clásico" del erotismo, pues su narrador es el adolescente Saturnin que, al husmear a través de un orificio en la pared de su cuarto, observó a su madre con un monje estar "haciendo aquello que hicieron nuestros primeros padres cuando Dios les ordenó poblar la tierra". ${ }^{59}$

Al observar tal espectáculo, el joven Saturnin inicia sus peripecias, que -en palabras de Robert Darnton- van desde practicar ese tipo de gimnasia con su hermana hasta el ejercicio de la sodomía en el convento donde él mismo se interna. ${ }^{60}$

Después de leer la denuncia, los inquisidores ordenaron de inmediato al padre Bolea que recogiera el libro en cuestión, con ayuda del brigadier Pedro Ruiz. Así se realizó, previa declaración del alférez Santiañés, quien indicó que la Histoire se la había prestado Juan Bautista Maestry, el cadete previamente señalado por el bachiller López. Incontinenti se efectuó el interrogatorio del denunciado, quien refirió el libro que había entregado al brigadier Garibay el año anterior y aseguró que no sabía cómo aquel título había llegado a su poder, pues cuando llegó a la Ciudad de México lo sacó de su baúl "sin saber quién se lo había introducido". ${ }^{61}$ Asimismo, aseguró que la obra de Gervaise de Latouche se la había prestado el cirujano de su regimiento, Francisco de Paula y Valdés.

Podrá imaginarse el lector que la siguiente diligencia inquisitorial fue interrogar a este último, quien confesó haber comprado muchos libros en conjunto, tanto a los negros de las colonias francesas como a los soldados de Tolón, "aún sin registrar su contenido por lo casi dados en los que se los vendían". 62 Sin embargo, nunca observó que aquel título estuviera entre sus libros, que durante su estancia en Xalapa los dejaba sobre la mesa de su habitación, arguyendo así que cualquier persona que hubiera entrado en su estancia pudo haber tomado sin su consentimiento aquel libro que él ignoraba tener.

\footnotetext{
58 Jean-Charles Gervaise de Latouche, Histoire de dom $B^{\star \star \star \star \star *}$, portier des Chartreaux, écrite par lui-même (Fráncfort: J. J. Trotener, 1748), acceso el 14 de septiembre de 2020, https:// gallica.bnf.fr/ark:/12148/bpt6k1513537b.r=Historie\%20de\%20Dom\%20B?rk=42918;4.

${ }_{59}$ Dictionnaire des cuvres érotiques, prefacio de Pascal Pia (París: Robert Laffont, 2001), 211. Traducción de la autora.

${ }^{60}$ Robert Darnton, El coloquio de los lectores (México: FCE, 2016), 93-95.

${ }^{61}$ AGN, Inquisición, vol. 1373, exp. 11, ff. 106, 108.

62 Ibid., f. 109.
} 


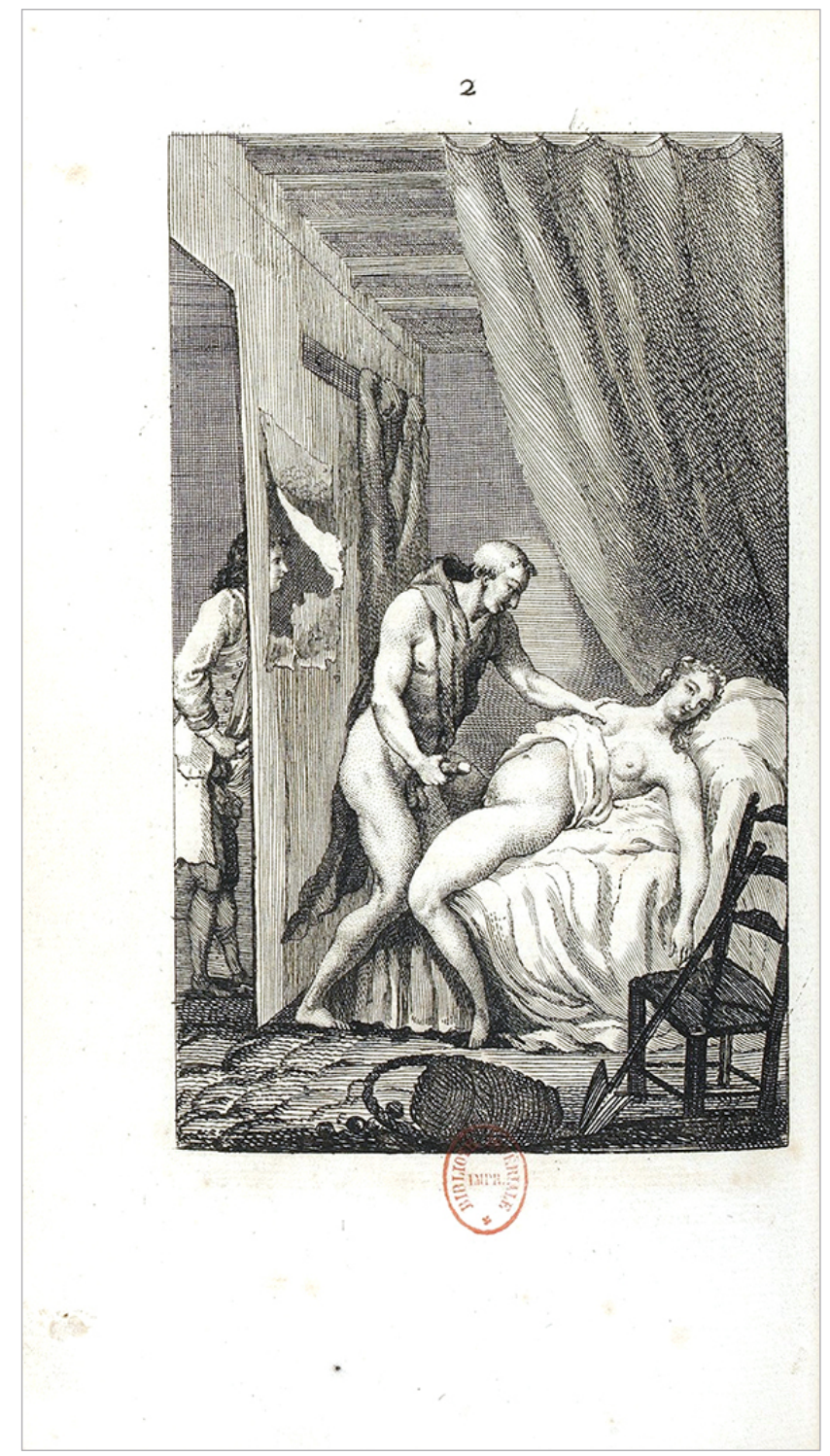

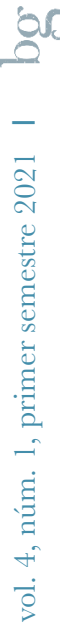

Imagen 6. Libro considerado un "clásico" del erotismo francés. Grabado de la obra de Jean-Charles Gervaise de Latouche, Histoire de dom $B^{\star \star \star \star \star}$, portier des Chartreaux, écrite par lui-même (Fráncfort: J. J. Trotener, 1748). BNF. 
Como he mencionado, no es raro que los militares poseyeran libros considerados obscenos, y al parecer los miembros del Regimiento de Infantería de Nueva España aprovecharon su movilidad en los territorios americanos para hacerse de este tipo de obras. Así lo denunció Juan José Erasso, capitán del Regimiento de la Corona, ante el comisario de Veracruz en marzo de 1798. El capitán indicaba haber estado en el cuartel de aquella ciudad con varios militares. Durante la reunión se había comentado que después de una estancia en Guárico, varios sujetos de la oficialidad del Regimiento de Nueva España habían introducido al virreinato varios libros "con estampas que demuestran diversos modos en que puede practicarse la fornicación". En esa misma ocasión se enteró el denunciante de que el subteniente Puerto Carrero del regimiento mencionado había dispuesto en su habitación "doce cuadros con estampas instructivas de la diversidad de modos o posturas que representan los actos más provocativos". 63

Con el propósito de encontrar los libros citados, se encomendó al capellán del Regimiento de Nueva España, Ramón Texeida y Xaibo, acudir a la casa del subteniente para examinar sus libros. Por desgracia para los inquisidores, Puerto Carrero falleció en la ciudad de Puebla de los Ángeles sin que el capellán consiguiera efectuar la diligencia. ${ }^{64}$

Otro expediente que ayuda a ilustrar el concepto de "obscenidad" en el siglo XVIII es el formado en contra de Miguel Avilés, hijo del marqués de Avilés. ${ }^{65}$ Se trata de un militar que comenzó su carrera en las filas del Regimiento de Dragones de Lusitania; ${ }^{66}$ en 1764 fue parte de la expedición de Juan de Villalba y

${ }^{63}$ Ibid., f. 113.

${ }^{64}$ Ibid., f. 122.

${ }^{65}$ El marqués de Avilés fue un militar que contribuyó a la defensa de Gibraltar. Ostentó diferentes cargos en el ejército español y su trayectoria le permitió ejercer puestos políticos como el de corregidor de Vich y Zaragoza, intendente de Saboya, Galicia, Valencia y Aragón, además de ser consejero de guerra. Ricardo Franch Benavent, "Las oportunidades de enriquecimiento ilícito generadas por el ejercicio de la intendencia más 'tentadora' de España: la pesquisa realizada al marqués de Avilés como intendente de Valencia en 1762", Estudis: Revista de Historia Moderna, núm. 28 (2002): 263-286. Fabrice Abbad y Didier Ozanam, Les intendants espagnols du XVIIIe siècle (Madrid: Casa de Velázquez, 1992), 58. ${ }_{66}$ Juan Delapuerta Cano, "Estructura orgánica y desarrollo histórico del regimiento de caballería Lusitania (1709-2010)" (tesis de doctorado, Universidad Cardenal Herrera-CEU, 2015), 374, acceso el 14 de septiembre de 2020, https://repositorioinstitucional.ceu. es/bitstream/10637/7311/1/Estructura\%20org\%c3\%a1 nica\%20y\%20desarrollo\%20 hist\%c3\%b3rico\%20del\%20regimiento\%20de\%20caballer\%c3\%ada\%20Lusitania\% 20\%281709-2010\%29_Primera\%20Parte_Tesis_Juan\%20Delapuerta\%20Cano.pdf. 
Angulo, quien tuvo el encargo de reformar el ejército de Nueva España. En este virreinato, Miguel fungió desde 1767 como teniente coronel del Regimiento de Dragones de España ${ }^{67} y$, aunque su labor implicaba viajes constantes entre Veracruz y Puebla, ${ }^{68}$ residió de forma regular en la Ciudad de México, donde -un año después de su nombramiento como teniente coronel- llegó al tribunal inquisitorial una denuncia en su contra. Su antigua sirvienta, María Josepha Carabantes, informó a los inquisidores que Avilés usaba "un libro lleno de estampas muy obscenas, con las más torpes demostraciones de hombres y mujeres". ${ }^{69}$ Esta obra, proseguía la denunciante, la había mostrado a Ricardo Potes y Prudencio León, quienes acompañaban un día al teniente coronel en su casa.

Ambos visitantes eran soldados del mismo regimiento, por lo que tenían una relación de subordinación con Avilés, lo cual permite suponer que tal vez el miedo o respeto a su superior invadió a Ricardo Potes cuando -al comparecer ante el comisario Domingo Pedro de Arrieta, el 11 de abril de 1768- negó conocer la razón por la que lo habían mandado llamar. Sin embargo, después de que el comisario le advirtiera que el Santo Tribunal tenía información en su contra, el soldado Potes no dudó en declarar que en casa del teniente coronel Miguel Avilés había visto, una sola vez, tres libros en octavo forrados en pasta y en idioma francés, que llevaban por título La Academia de las Damas. Nueve días después, al ser requerido, el soldado Prudencio León compareció ante el mismo comisario y -seguramente advertido del asunto por Potes- de manera inmediata confesó haber visto el mismo libro en casa de Avilés. ${ }^{70}$

La obra en cuestión es considerada un best seller de la tradición erótica francesa del siglo XVIII, ${ }^{71}$ fue escrita en latín por Nicolas Chorier e impresa en Lyon en 1660 bajo el título de Aloisiae Sigoear Toletanae Satyra Sotadica de arcanis amoris et Veneris. Aloisa hispanice scripsit, latinitate donavit Joannes Meursius V. C. Sin embargo, a mediados de ese siglo la adaptó el abate Jean Terrasson, y cambió su título a L'Academie des Dames ou les sept entretiens galants d'Aloisa. Seguramente la edición que poseyó Miguel Avilés fue la correspondiente al año

\footnotetext{
${ }^{67}$ AGN, Correspondencia de Virreyes, vol. 17; y AGN, Reales Cédulas Originales, vol. 90, exp. 46.

${ }^{68} \mathrm{Su}$ cargo le demandaba trasladarse en ocasiones a Puebla, para supervisar las compañías que estaban bajo su mando en Veracruz. AGN, Indiferente Virreinal, caja 0989, exp. 30, ff. 11, 15.

${ }^{69}$ AGN, Inquisición, vol. 1075, exp. 1, ff. 1-6 y 3v.

${ }^{70} \mathrm{lbid}$., ff. 5 r y $5 \mathrm{v}$-6r.

${ }^{71}$ Darnton, Los best sellers, 157.
} 


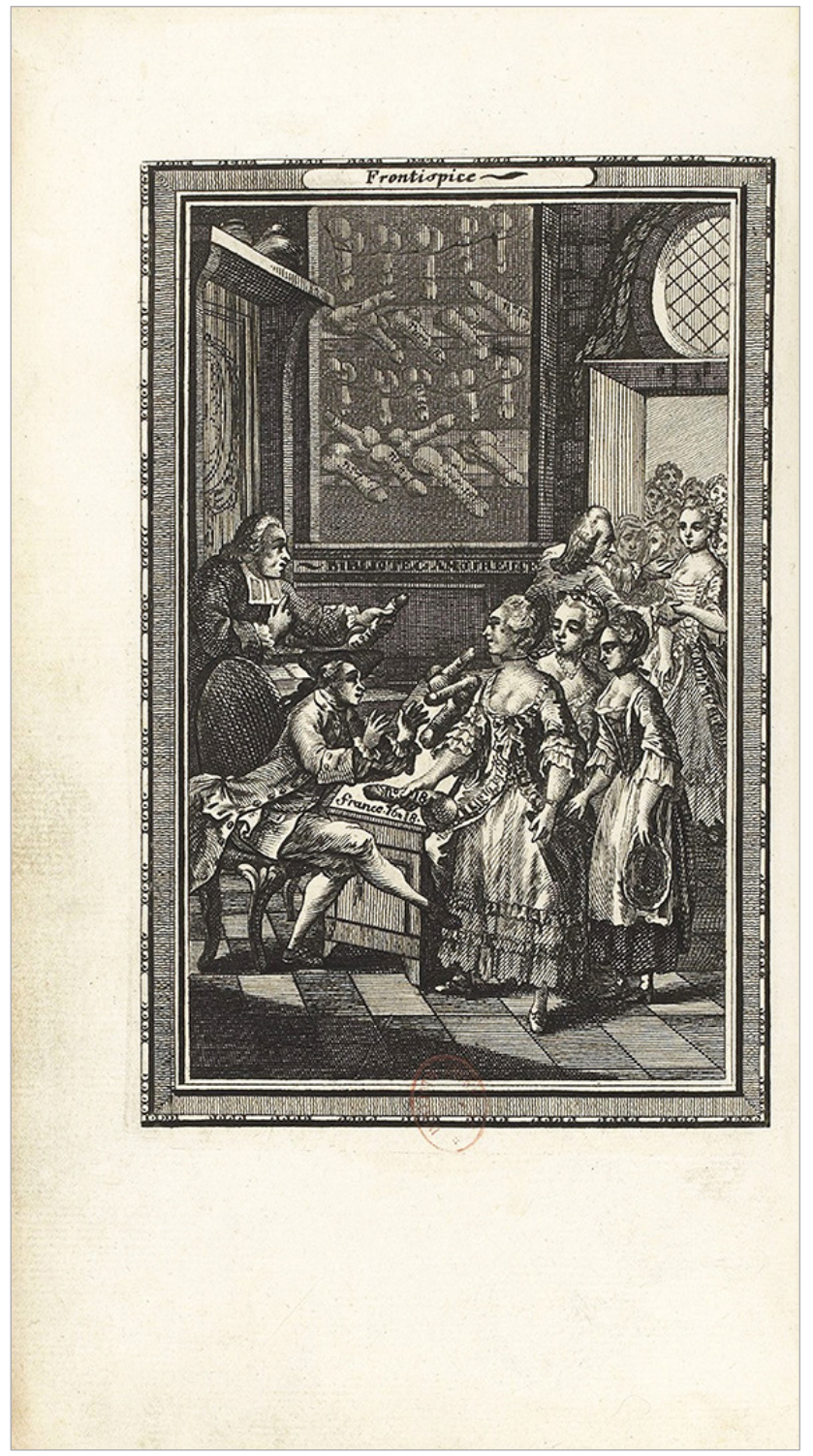

Imagen 7. Un best seller francés estuvo en manos del militar Miguel Avilés. Frontispicio de Nicolas Chorier, L'Académie des Dames (Venecia: Pierre Arretin, 1770). BNF. 
$1770,{ }^{72}$ la cual presentaba varias imágenes que podían considerarse contrarias a las reglas VII y XI de los Índices.

Así, en virtud del edicto ${ }^{73}$ de 1768 , en el que se prohibían "las pinturas lascivas", 74 María Josepha denunció a Avilés, aunque esta obra todavía no figuraba en la lista de libros, pues sería prohibida en España hasta el año 1779. ${ }^{75}$

Siguiendo las órdenes de los señores inquisidores, el comisario acudió en noviembre de 1768 al número 38 de la calle de las Cocheras, con el fin de recoger ese libro obsceno. Para su sorpresa, Miguel Avilés expresó "no tener ninguno de semejante naturaleza", dijo que era cierto haberlo tenido, pero no recordaba si lo había prestado a alguno de sus superiores, entre quienes se encontraban Antonio Ricardo y el marqués de Rubí, mariscales de campo comisionados para arreglar las milicias en la costa de Veracruz y en la capital, respectivamente. ${ }^{76}$

El teniente coronel Avilés se mostró muy amable, e incluso sugirió al comisario que reconociera los libros que tenía en su estudio, agregando "que ponía de manifiesto los baúles y toda la casa". Ignoramos si el comisario aceptó la propuesta de Avilés, pero si lo hubiera hecho, es probable que no encontrara algún libro sospechoso, puesto que la averiguación fue suspendida dos días después de que el comisario inquisitorial redactara las últimas noticias sobre el caso. ${ }^{77}$

Cabe mencionar que, en ocasiones, los grabados de las obras literarias se utilizaban para adornar algunos objetos de uso cotidiano, como en el caso de un reloj de bolsillo que utilizó Agustín Beven, coronel de Dragones de México. Originario de Bayona (Francia) había desarrollado su carrera militar en Alemania y España de 1744 a 1763, cuando arribó a Nueva España, en donde ejerció hasta su muerte, ocurrida en 1797. Durante su desempeño militar en el virreinato, en distintas ocasiones fue denunciado por poseer libros prohibidos,

\footnotetext{
72 Dictionnaire des œuvres érotiques, 14-15. Nicolas Chorier, L'Académie des Dames (Venecia: Pierre Arretin, 1770), acceso el 14 de septiembre de 2020, https://gallica.bnf.fr/ ark:/12148/bpt6k1520381d/f1.image.vertical.

${ }^{73}$ Los edictos instaban a que los fieles denunciaran ante el Tribunal a quienes hicieran o dijeran alguna cosa contraria al dogma cristiano, o en contra el mismo tribunal. Ramos Soriano, Los delincuentes de papel, 97-143.

${ }^{74}$ AGN, Inquisición, vol. 1075, exp. 1, f. 3r.

${ }^{75}$ Marcelin Defourneaux, Inquisición y censura de libros en la España del siglo XVIII (Madrid: Taurus, 1973), 249.

${ }^{76}$ María del Carmen Velázquez, El estado de guerra en Nueva España, 1760-1808 (México: Colmex, 1997), 69.

${ }^{77}$ AGN, Inquisición, vol. 1075, exp. 1, ff. 1 y 2.
} 
pero no fue sino hasta después de su deceso cuando los inquisidores conocieron los libros que conformaban su biblioteca. ${ }^{78}$

Poco antes de morir, el coronel Beven nombró albacea a Joseph Arias, quien con ayuda del alférez Tomás del Espíritu Santo formó el inventario y las almonedas de sus bienes. ${ }^{79}$ Sin embargo, no todos se integraron a esa lista, pues al examinar sus libros se reconocieron 33 títulos prohibidos que, sellados y lacrados, fueron remitidos al Tribunal de la Fe para su calificación. ${ }^{80}$ En la minuta enviada a la Inquisición se registraban dos tomos en francés con el título de Cuentos y novelas de Mr. de La Fontaine, impresos en Ámsterdam (1762). El calificador Francisco de Solís Casaus indicó que de este autor sólo estaban permitidas las fábulas. En efecto, en el edicto publicado en Nueva España el 27 de agosto de 1761 se había prohibido la totalidad de esos tomos, en cualquier impresión que se hallaran, por ser considerados "deshonestos y peligrosos".81

El primer tomo de esta obra había sido publicado en Francia desde 1665, "como relatos para divertir". El segundo tardó un año más en aparecer y fue objeto de tan buena acogida como el primero. El tercero apareció en 1671 y el último sólo vio la luz de manera clandestina en $1674 .{ }^{82}$ En todos sus tomos, el autor francés reunía una serie de relatos cortos sobre engaños conyugales, artificios e infidelidad de las mujeres, al igual que pasajes de curas y monjas involucradas en amoríos ${ }^{83}$ Temáticamente estaban basados en tres obras: el Decamerón de Giovanni Boccaccio, Les cent nouvelles nouvelles atribuidas a Antoine de la Sale y Nouvelles récréations et joyeux devis de Margarita de Navarra, así como en relatos orales que La Fontaine simplificó, transformó y presentó en verso. ${ }^{84}$

La edición que poseía Beven había sido impresa en Ámsterdam y constaba de dos tomos en octavo que reunían las cuatro partes de la obra. En el

78 Sobre la vida y lecturas de este militar, consultar María Elvira Buelna Serrano, Proceso inquisitorial contra don Agustín Beven, coronel del Regimiento de Dragones de México (México: UAM, 1987) y Marcelino Trigueros, "Persecución inquisitorial del libro en el siglo XVIII novohispano: el caso del coronel Agustín Beven (1767-1797)" (tesis de doctorado, Universidad de Alicante, 2017), acceso el 14 de septiembre de 2020, https:// dialnet.unirioja.es/servlet/tesis?codigo $=134007$ \&orden $=0 \&$ info=link.

${ }^{79}$ Archivo General de Indias, Diversos, vol. 49, exp. 9.

${ }^{80}$ AGN, Indiferente Virreinal, caja 3189, exp. 10.

${ }^{81}$ Ibid., Inquisición, Edictos, vol. II.

82 Jean de la Fontaine, Cuentos y relatos en verso, ed. de Miguel Ángel García Peinado (Madrid: Cátedra, 2002), 12-13.

${ }^{83}$ Buelna Serrano, Proceso inquisitorial, 47.

${ }^{84}$ Fontaine, Cuentos y relatos, 9-21. 
prólogo, La Fontaine señaló que una de las críticas hecha a sus cuentos era que se trataba de un libro lascivo, consideración que el autor rechazó al argumentar que así era la naturaleza del cuento y suprimir algunas cosas le hubiera quitado la gracia, esto es, la finalidad de la escritura. ${ }^{85}$ De esta manera iniciaba sus Cuentos, los cuales estaban acompañados de cabeceras (imágenes situadas al comienzo de cada capítulo) y remates (ilustraciones al final) diseñados por Pierre Philippe Choffard, así como de 82 imágenes grabadas por el artista flamenco Charles Eisen, reconocido por ilustrar libros con temas eróticos. ${ }^{86}$

Además de ser denunciado por poseer libros prohibidos, Agustín Beven fue acusado de tener un reloj de bolsillo decorado con una imagen que "contenía por la parte interior de la caja, una pintura disfrazada con su tapa que se corría por medio de un muelle; en la que se representaba la figura de un hombre del campo en ademán de estar pintando un asno a su mujer en las partes pudendas". ${ }^{87}$ En mi opinión, es posible identificar esta descripción en la obra de La Fontaine bajo el título "Las albardas". A continuación, el relato:

Hubo un pintor celoso de su mujer, que al ausentarse le dibujó un borrico sobre el ombligo, a modo de candado. Un compañero, prendado de la dama, se fue a su encuentro: de un golpe borró el asno.

Dios sabe cómo: dibujóle otro en ese sitio, así parece ser.

Al nuevo burro, por un error u olvido, le puso albardas que el otro no tenía.

Vuelto el esposo, quiso aclarar el hecho:

"Ved, mi señor, explícale la comadre, el asno es prueba de mi fidelidad".

"¡Manda narices, dijo él muy enfadado, también es prueba de que alguien lo ha albardado!".88

\footnotetext{
${ }^{85}$ Fontaine, Contes et nouvelles en vers (Ámsterdam: Barbou, 1762), acceso el 14 de septiembre de 2020, https://gallica.bnf.fr/ark:/12148/btv1b8615778r/f11. planchecontact.r= Contes\%20et\%20Nouvelles\%20en\%20vers.

${ }^{86}$ Svend Dahl, Historia del libro (México: Conaculta / Alianza Editorial, 1982), 188.

${ }^{87}$ AGN, Inquisición, vol. 1167, exp. 23, ff. 375-378.

${ }^{88}$ Fontaine, Cuentos y relatos, 497.
} 


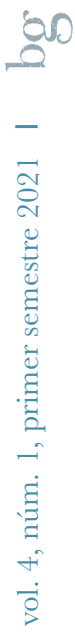

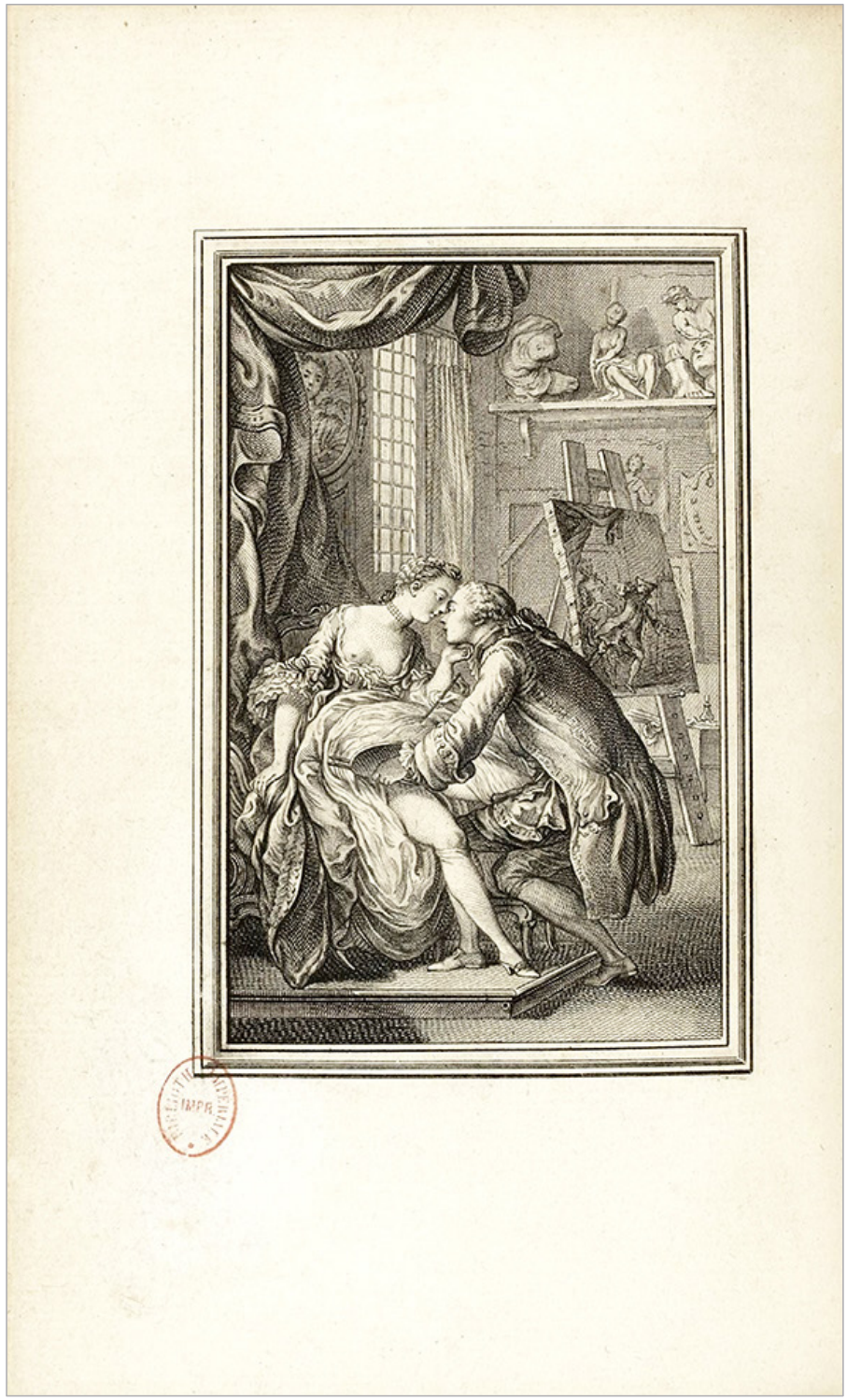

Imagen 8. Grabado en el reloj de bolsillo del coronel Agustín Beven.

Acompaña al cuento "Las albardas". Jean de la Fontaine, Contes et nouvelles en vers, t. II (Ámsterdam: Barbou, 1762). BNF. 
El coronel Beven poseyó otro objeto que escondía una imagen obscena: una cajita, señalada por Rafael Velázquez de la Cadena durante un interrogatorio que tuvo como objetivo indagar sobre algunas proposiciones enunciadas por el coronel. Al momento de preguntarle si conocía el motivo por el cual había sido llamado, Velázquez no habló de las proposiciones, sino que supuso que el llamado era "por razón de unas cajas obscenas que le han dicho tienen diferentes sujetos de la ciudad", refiriéndose a Beven, a Francisco Rojas y Rocha -alcalde mayor de Teposcolula- y a Antonio Rodríguez de Pedroso y Soria, segundo conde de San Bartolomé de Xala. ${ }^{89}$

Desde el siglo XVI, el consumo del tabaco estaba relacionado con los beneficios que se creía que brindaba. Fumada, la planta era considerada medicinal, pues pensaban que el humo ofuscaba "el sentido de las penas y los trabajos", produciendo en el consumidor una sensación de "reposo de todas las potencias (que podía casi llamarse embriaguez)". Acerca del polvo de las hojas inhalado (rapé), se decía: "hace que no se sientan los azotes o los suplicios de cualquier género, aumenta el vigor, y fortalece el ánimo para llevar los trabajos". ${ }^{90}$ Los hombres y mujeres del siglo XVIII solían tener varias de esas cajitas en las que portaban el tabaco, ya fuera como rapé, cigarrillos o simplemente las hojas trituradas.

El coronel de dragones Agustín Beven poseía una cajita con un funcionamiento sofisticado. Tenía "una representación muy obscena de hombre y mujer disimulada, o cubierta con betún que aplicado el fuego se recoge de forma que quedan descubiertas las figuras, y separando el fuego vuelve a tomar extensión el betún para cubrirlas"..$^{1}$ Era redonda y, según declaró Velázquez de la Cadena, se la habían regalado al coronel durante su estancia en Xalapa. Para desgracia de los inquisidores, no pudo ser recogida porque al ser interrogado Beven dijo haberla obsequiado al teniente de fragata Juan Antonio de la Bodega y Cuadra, quien había marchado a Lima.

La cajita que poseía don Francisco Rojas y Rocha, también relacionado con las armas al fungir como comisario de guerra, era ovalada y había sido fabricada en París, con un mecanismo accionado mediante dos resortes. Al activar uno aparecía en el centro la pintura de una niña en representación decente y

\footnotetext{
${ }^{89}$ AGN, Inquisición, vol. 1113, exp. 28, ff. 17-20.

90 Manuel González Galván, El tabaco y las cigarreras mexicanas de oro y plata (México: UNAM, 1980), 29.

${ }^{91}$ AGN, Inquisición, vol. 1167, exp. 23, ff. 375-378.
} 
al quitar el segundo se descubría lo obsceno, es decir, una mujer desnuda, de espaldas, al salir de bañarse. ${ }^{92}$ Por último, el segundo conde de Xala se desempeñaba como capitán comandante de fusileros. Se sabe que poseía varias cajas para tabaco con un valor muy alto. De ellas Ilaman la atención dos, una valuada en 200 pesos, de particular hechura pues era de oro y esmalte azul, guarnecida de chispas de diamantes y rubíes, su tapa estaba decorada con dos figuras pintadas en miniatura. El avalúo de la otra era de 150 pesos, con forma oval, de piedra jaspe y guarnecida de oro, diamantes, esmeraldas y rubíes. ${ }^{93}$

En cambio, la caja denunciada a la Inquisición por Velázquez de la Cadena no era suntuosa. Era redonda, de cartón, acharolada o barnizada, con una piedra blanca en el centro. Por tanto, al parecer laqueada, ${ }^{94}$ podía carecer de valor material y quizá su mayor valía era la imagen entonces considerada "escandalosa", de la cual no tenemos referencia. La técnica de fabricación indica que se trataba de una cajita procedente de algún lugar de Asia, probablemente de China o Japón.

No obstante, hay que indicar que su fabricación también pudo haber sido europea ya que, como ha señalado Elias Russel:

en todos los países se fabricaron cajitas para contener el polvo del tabaco, en grandes cantidades; los materiales empleados principalmente fueron el oro y la plata, cincelados o esmaltados; cobre esmaltado con brillante de policromía, carey, nácar, laca desde el periodo rococó, la porcelana pintada con preciosas miniaturas (la Fábrica del Buen Retiro creó modelos admirables). Finalmente se hicieron también en papier-maché a bajo precio. ${ }^{95}$

\footnotetext{
$92 \mathrm{lbid}$.

${ }^{93}$ Manuel Romero de Terreros, Una casa del siglo XVIII en México, el conde de Xala (México: UNAM, 1957), 60.

${ }^{94}$ La base del laqueado es "la savia seca de un árbol llamado rhus vernicifera, del este de Asia, el cual gotea en las estaciones de verano y otoño. La laca, al contacto con el aire se vuelve negra, y posteriormente se depura antes de ser utilizada, consigue un alto grado de dureza y cuando se aplica a objetos forma un barniz duro y resistente, y lo que es más llamativo, luminoso y brillante". Rosario María Díaz Martín, Descubrir y conocer el coleccionismo y las antigüedades (Madrid: LIBSA, 2006), 305-308.

${ }^{95}$ Elias Russel, "Cajita de rapé", acceso el 14 de septiembre de 2020, http://www.museo delprado.es.
} 
El destino de estas dos últimas cajitas fue incierto, ya que por órdenes del Tribunal fueron recogidas y a pesar de que los dueños pidieron que se las devolvieran, no hay registro de que así haya ocurrido. Cabe mencionar que si bien eran fabricadas para portar tabaco, estas cajitas también tuvieron otros usos: contenedores para diversos afeites, para guardar los lunares artificiales que las mujeres usaban, o como bomboneras.

\section{Conclusiones}

Desde el establecimiento del Tribunal del Santo Oficio en Nueva España, la obscenidad plasmada en pinturas y libros estuvo prohibida según las reglas VII y XI de los Índices de libros prohibidos, las cuales regulaban la producción y el consumo de las obras artísticas. Al analizar diversos expedientes inquisitoriales, podemos afirmar que estas normas no se respetaron del todo en el virreinato novohispano durante la segunda mitad del siglo XVIII. Hombres entre los 20 y los 50 años, que se desempeñaron principalmente como comerciantes, militares y empleados reales, utilizaron gran diversidad de productos considerados obscenos, tanto por sus denunciantes como por la autoridad inquisitorial.

En cuanto a los consumidores, no hay que olvidar a las monjas del Convento de las Capuchinas de Guadalajara, cuyas identidades aún desconocemos. Asimismo, debe destacarse la abundancia de casos registrados en contra de militares poseedores de libros y otros objetos calificados como obscenos, al igual que la actitud que mostraron frente a las denuncias de este tipo y la habilidad con la que evadieron la autoridad inquisitorial.

Como queda dicho, en algunas ocasiones estos productos fueron manufacturados en Asia o en Europa, llegaban a los puertos del virreinato para después ser distribuidos o vendidos a lo largo del territorio en locales, tiendas o mercerías. En otros casos, estos objetos fueron elaborados por manos novohispanas. Recordemos, por ejemplo, el manuscrito "Amor del Tiempo", así como las producciones de los pintores José Alfaro y José Salazar. Ya fueran producidos en el extranjero o dentro del virreinato, estos artículos considerados obscenos eran usados como alhajas, entre las que podemos encontrar botones, relojes y cajitas para tabaco.

Las estampas, por otro lado, al tiempo que eran utilizadas como herramienta de trabajo, decoraban alguna habitación, como en el caso del académico Luis Martín. Finalmente, las páginas de los libros obscenos narraban las 
experiencias sexuales de los personajes principales y estaban adornadas con ilustraciones de la misma naturaleza, las cuales resumían tales escenas.

En cuanto a las características y descripción de estos objetos, podemos decir que en ellos se podían encontrar dibujos de mujeres cuyo atuendo, calificado de obsceno en alguna de sus partes, seguía la moda del siglo, que hoy aún podemos apreciar en algunos retratos elaborados en la temporalidad abarcada. De igual manera, el observador podía descubrir cuerpos desnudos y representaciones del acto sexual, imágenes consideradas obscenas y que sin duda debieron impresionar no solamente debido a su contenido, sino también por la riqueza plástica que mostraban las imágenes.

\section{Referencias}

Abbad, Fabrice y Didier Ozanam. Les intendants espagnols du XVIIIe siècle. Madrid: Casa de Velázquez, 1992.

Apollinaire, Guillaume. Introducción y ensayo bibliográfico a L'Oeuvre du chevalier Andréa de Nerciat, de Andréa Nerciat, 1-55. París: Bibliothèque des Curieux, 1921.

Archivo General de Indias. España. Fondo Diversos.

Archivo General de la Nación (AGN). México. Ramos Inquisición, Correspondencia de Virreyes, Reales Cédulas Originales, Indiferente Virreinal.

Bello, Kenya. "Una biblioteca para artistas. La Academia de San Carlos y la lectura pública (1785-1843)". En Estantes para los impresos. Espacios para los lectores. Siglos XVII-XIX. Coordinación de Laura Suárez de la Torre, 215-248. México: Instituto de Investigaciones Dr. José María Luis Mora / Consejo Nacional de Ciencia y Tecnología, 2017.

Buelna Serrano, María Elvira. Proceso inquisitorial contra don Agustín Beven, coronel del Regimiento de Dragones de México. México: Universidad Autónoma Metropolitana, 1987.

Chorier, Nicolas. L'Académie des Dames. Venecia: Pierre Arretin, 1770. Acceso el 14 de septiembre de 2020. https://gallica.bnf.fr/ark:/12148/bpt6k $1520381 \mathrm{~d} / \mathrm{f1}$.image.vertical.

Curiel, Gustavo. "Ovidio censurado: los lienzos de pintura lasciva del marqués de Celada (historia de un proceso inquisitorial, 1692)". En La abolición del arte. XXI Coloquio Internacional de Historia del Arte. Edición de Alberto 
Dallal, 273-315. México: Universidad Nacional Autónoma de México, Instituto de Investigaciones Estéticas, 1998.

Dahl, Svend. Historia del libro. México: Consejo Nacional para la Cultura y las Artes / Alianza Editorial, 1982.

Darnton, Robert. Los best sellers prohibidos en Francia antes de la Revolución. México: Fondo de Cultura Económica, 2014.

Darnton, Robert. El coloquio de los lectores. México: Fondo de Cultura Económica, 2016.

Defourneaux, Marcelin. Inquisición y censura de libros en la España del siglo XVIII. Madrid: Taurus, 1973.

Delapuerta Cano, Juan. "Estructura orgánica y desarrollo histórico del regimiento de caballería Lusitania (1709-2010)". Tesis de doctorado. Universidad Cardenal Herrera-CEU, 2015. Acceso el 14 de septiembre de 2020. https://repositorioinstitucional.ceu.es/bitstream/10637/7311/1/Estructura\%20org\%c3\%a1 nica\%20y\%20desarrollo\%20hist\%c3\%b3rico\%20del \%20regimiento\%20 de\%20caballer\%c3\%ada\%20Lusitania\%20\% 281709-2010\%29_Primera\%20Parte_Tesis_Juan\%20Delapuerta\%20 Cano.pdf.

Díaz Martín, Rosario María. Descubrir y conocer el coleccionismo y las antigüedades. Madrid: LIBSA, 2006.

Dictionnaire des œuvres érotiques. Prefacio de Pascal Pia. París: Robert Laffont, 2001.

Fernández López, Juana Inés, Jorge René González M. et al. Vocabulario eclesiástico novohispano. México: Instituto Nacional de Antropología e Historia, 2015.

Fontaine, Jean de la. Contes et nouvelles en vers. Ámsterdam: Barbou, 1762. Acceso el 14 de septiembre de 2020. https://gallica.bnf.fr/ark:/12148/ btv1 b8615778r/f11. planchecontact.r=Contes\%20et\%20Nouvelles\%20 en\%20vers.

Fontaine, Jean de la. Cuentos y relatos en verso. Edición de Miguel Ángel García Peinado. Madrid: Cátedra, 2002.

Franch Benavent, Ricardo. "Las oportunidades de enriquecimiento ilícito generadas por el ejercicio de la intendencia más 'tentadora' de España: la pesquisa realizada al marqués de Avilés como intendente de Valencia en 1762". Estudis: Revista de Historia Moderna, núm. 28 (2002): 263-286. 
Gacto, Enrique. "El arte vigilado (sobre la censura estética de la Inquisición española en el siglo XVIII)". Revista de la Inquisición 200, núm. 9 (2000): 7-68.

Galván González, Victoria. "La literatura erótica de la Ilustración española". En La palabra y el deseo. Estudio de literatura erótica. Coordinación de Germán Santana Henríquez, 117-134. Gran Canaria: Universidad de Las Palmas de Gran Canaria, 2002.

Gavarrón, Lola. Piel de ángel. Historias de la ropa interior femenina. Barcelona: Tusquets, 1988.

Gervaise de Latouche, Jean-Charles. Histoire de dom $B^{\star \star \star \star *}$, portier des Chartreux, écrite par lui-même. Fráncfort: J. J. Trotener, 1748. Acceso el 14 de septiembre de 2020. https://gallica.bnf.fr/ark:/12148/bpt6k1513537b. $r=$ Historie\%20de\%20Dom\%20B?rk=42918;4.

Gies, David T. "Sobre el erotismo rococó en la poesía del siglo XVIII español". En Luz Vital: estudios de cultura hispánica en memoria de Victor Ouimette. Edición de Ramón F. Llorens y Jesús Pérez Magallón, 85-95. Alicante: Caja de Ahorros del Mediterráneo, 1999.

Gómez de Silva, Guido. Diccionario breve de mexicanismos. México: Fondo de Cultura Económica, 2004.

González Galván, Manuel. El tabaco y las cigarreras mexicanas de oro y plata. México: Universidad Nacional Autónoma de México, 1980.

Kamen, Henry. La inquisición española. Barcelona: Crítica, 2013.

Martínez Bujanda, Jesús. "Literatura e Inquisición". En La Inquisición española: una nueva visión, nuevos horizontes. Coordinación de Joaquín Pérez Villanueva, 579-592. México: Siglo XXI, 1980.

Masera, Mariana. "Bailes 'deshonestos' y sones perseguidos por la Inquisición novohispana". En Poéticas de la oralidad: las voces del imaginario. Edición de Mariana Masera, 79-110. México: Universidad Nacional Autónoma de México, 2014.

Mayer, Alicia. Lutero en el Paraíso. La Nueva España en el espejo del reformador alemán. México: Fondo de Cultura Económica, 2008.

Maza, Francisco de la. "José Luis Rodríguez Alconedo". Anales del Instituto de Investigaciones Estéticas, núm. 6 (1940): 39-56.

Miranda, José y Pablo González Casanova. Sátira anónima del siglo XVIII. México: Fondo de Cultura Económica, 1953. 
Moreno Silva, Désirée. "Erotismo y censura en el siglo XVIII novohispano. Imágenes y objetos censurados por la Inquisición". En XXIII Coloquio Internacional de Historia del Arte. Amor y Desamor en las Artes. Edición de Arnulfo Herrera Curiel, 353-373. México: Universidad Nacional Autónoma de México, 2001.

Muñoz García, María José. "La censura inquisitorial de publicaciones obscenas". En Inquisición y censura: el acoso a la inteligencia en España. Coordinación de Enrique Gacto Fernández, 503-525. Madrid: Dykinson, 2006.

Muñoz García, María José. "Erotismo y celo inquisitorial. Expedientes de escritos obscenos censurados por la Inquisición en el siglo XVIII y principios del XIX". Cuadernos de Historia del Derecho, núm. 10 (2003): 157-207.

Nerciat, André-Robert [Andréa Nerciat]. Félicia ou mes fredaines, orné de figures en taille-douce. Tome 1, Partie 1. Londres, 1782. Acceso el 14 de septiembre de 2020. https://gallica.bnf.fr/ark:/12148/bpt6k1073304q/f13.plan checontact.r=F\%C3\%A9licia\%20ou\%20Mes\%20fredaines.

O'Phelan Godoy, Scarlett. "La moda francesa y el terremoto de Lima". Bulletin de I'Institut Français d'Études Andines 36, núm. 1 (2007): 19-38.

Peakman, Julie. Amatory Pleasures: Explorations in Eighteen-Century Sexual Culture. Londres; Nueva York: Bloomsbury Publishing, 2016.

Ramos Soriano, José Abel. Los delincuentes de papel. Inquisición y libros en la Nueva España (1571-1820). México: Fondo de Cultura Económica, 2011.

Romero de Terreros, Manuel. Una casa del siglo XVIII en México, el conde de Xala. México: Universidad Nacional Autónoma de México, 1957.

Russel, Elias. "Cajita de rapé". Acceso el 14 de septiembre de 2020. http://www. museodelprado.es.

Trigueros, Marcelino. "Persecución inquisitorial del libro en el siglo XVIII novohispano: el caso del coronel Agustín Beven (1767-1797)". Tesis de doctorado. Universidad de Alicante, 2017. Acceso el 14 de septiembre de 2020. https: //dialnet.unirioja.es/servlet/tesis?codigo=134007\&orden=0\&info=link.

Trousson, Raymond. "Andréa de Nerciat, Félicia ou mes fredaines, 1775". En Romans libertins du XVIIIe siècle. Coordinación de Raymond Trousson, 1051-1063. París: Robert Laffont, 1993.

Velázquez, María del Carmen. El estado de guerra en Nueva España, 1760-1808. México: El Colegio de México, 1997. 
Zavala, Iris. "Inquisición, erotismo, pornografía y normas literarias en el siglo XVIII". Anales de Literatura Española, núm. 2 (1983): 509-528. bg 